\title{
Assessment of Tractable Cysteines for Covalent Targeting by Screening Covalent Fragments
}

\author{
László Petri, Péter Ábrányi-Balogh, Imre Tímea, Gyula Pálfy, András Perczel, Damijan \\ Knez, Martina Hrast, Martina Gobec, Izidor Sosič, Kinga Nyíri, Beáta G. Vértessy, Niklas \\ Jänsch, Charlotte Desczyk, Franz-Josef Meyer-Almes, Iza Ogris, Simona Golič Grdadolnik, \\ Luca Giacinto Iacovino, Claudia Binda, Stanislav Gobec, György M. Keserű
}

\section{Introduction}

Targeted covalent inhibitors (TCIs) are important chemical biology tools and therapeutic agents.[1] TCIs form covalent bonds with nucleophilic residues, most often cysteine, but also others such as lysine, serine, threonine or tyrosine.[2] The advantages of TCIs include increased biochemical efficiency, prolonged duration of action leading to less frequent dosing, and an opportunity to target shallow binding sites, which were previously considered "undruggable".[3] TCIs initially interact with the target by forming a noncovalent complex, followed by the reaction of the electrophilic functional group (a "warhead") with the nucleophilic amino acid residue.[4] A closer look at electrophilic natural products reveals the presence of many reactive functionalities with diverse reaction mechanisms and varying intrinsic reactivities.[5] The most common TCI design strategy, however, pays less attention to the warheads[6] since they are typically attached to optimized noncovalent inhibitors.[7] By neglecting warhead reactivity optimization, this approach fails to enable the parallel optimization of covalent and noncovalent interactions that could contribute to the discovery of specific and safe covalent drugs. [8] Recent proteomic studies have suggested that the reactivity of cysteines is remarkably diverse in distinct proteins;[9] therefore, commonly used warheads should not be considered as the most suitable during the design process without experimental evaluation of their suitability. As mostly only computational approaches were used for the characterization of reactive cysteines,[6b,10] screening a diverse set of covalent fragments[11] represents an experimental alternative to these methods. Therefore, in contrast to previous studies,[12] our objective was not only to compare warheads reactivity, but to investigate the reactivity and accessibility of targeted cysteines with a set of covalent fragments, covering a suitable range of reactivity. To avoid the influence of noncovalent contributions, we equipped a single scaffold with a variety of warheads, composing a reactivity mapping toolbox. The constructed electrophilic fragment library was first characterized with experimental reactivity descriptors, aqueous stability and amino acid specificity information. These data confirmed their cysteine specificity and the range of reactivity covered. Then, we screened the library against proteins having different levels of functional and structural complexity (MurA, MAO-A, MAO-B, HDAC8, the immunoproteasome, and KRASG12C). Comparative profiling demonstrated that it is possible to pinpoint reactivityand accessibility-based specificity caveats for the individual target. Furthermore, the study suggested the optimal warheads for the design of covalent inhibitors for a target of interest.

\section{Results and Discussion}




\section{Mapping library design and characterization}

To investigate the reactivity of different warheads in an unbiased way, we equipped the 3,5bis(trifluoromethyl)phenyl group, a chemically stable and common motif in medicinal chemistry,[13] with different warheads. There are specific advan-tages of this scaffold. The limited size and complexity of the 3,5-bis(trifluoromethyl)phenyl fragment, which forms minimal noncovalent protein-ligand interactions, allowed screening against structurally diverse targets. Electron withdrawing prop-erties and the orientation of the trifluoromethyl groups enhance the electrophilic character of the warheads. Therefore, functional groups with lower reactivity could also be inves-tigated. After the proper analysis of the most common cysteinetargeting warheads,[6] we selected 28 covalent fragments representing 20 warhead chemotypes (Figure 1), with an average heavy atom count of $19 \pm 2$ and a molecular weight of $289 \pm 36$ $\mathrm{g} / \mathrm{mol}$. The library was assembled by acquiring com-pounds or their intermediates either from commercial sources or by synthesis (see the Experimental Section).

To test the reactivity range experimentally, we performed the thiol surrogate glutathione (GSH) reactivity assay (Table S1 in the Supporting Information),[12a,14] which showed that the library includes molecules from highly reactive fragments $(2,5,6,11,12,14,15$, and 24$)$ to GSH nonreactive compounds $(7,8,16,17,18,22$, and 28). Notably, the known reversible[15] binding of the cyano-acrylamide warhead (4) was confirmed. Next, the labelling efficiency and cysteine selectivity of the library members were evaluated against a nonapeptide model (KGDYHFPIC) containing multiple nucleophilic residues (Cys, His, Tyr, and Lys).[12a] Here, the cysteine selectivity of the fragments was confirmed. Furthermore, one should note that the fragments showed appropriate aqueous stability for biological testing (Table S1).

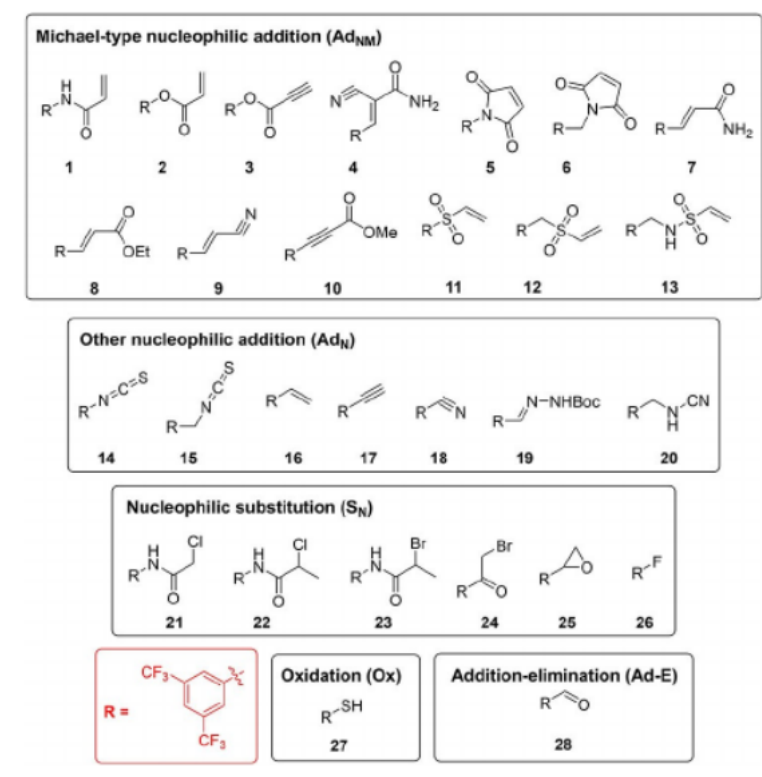

Figure 1. Covalent probes (1-28).

\section{Profiling cysteines' reactivity and accessibility}


Despite the usefulness of both surrogate model methods to obtain preliminary information on the reactivity and selectivity of warheads, we are well aware that these results do not always reflect events in complex biological systems. In our case, the results from the GSH reactivity assay and nonapeptide model were mostly, but not always, consistent with the results of enzyme assays (Tables 1 and S1).

Single concentration analyses against different protein targets were then performed to obtain preliminary reactivity profiles in a more complex system. As all library members had an identical scaffold, the reactivity heat map (Figure S1) suggested that the warhead chemotype had a significant impact on the labelling efficiency. Active warheads were identified in all chemical classes, and a trend that different tractable cysteines prefer different warhead chemotypes was also clear. A more detailed confirmation of the reactivity profiles was obtained by enzyme kinetic experiments.

\section{Profiling on MurA}

MurA (UDP-N-acetylglucosamine enolpyruvyl transferase) is a key enzyme in the biosynthesis of bacterial peptidoglycan precursors containing catalytic Cys115.[16] Single concentration screening showed that several fragments caused inhibition with residual activity (RA) between 0 and $50 \%$ (Figure S1) and these were subjected to IC50 measurements (Table 1). Notably, while in most cases the IC50 values fell in the range of 38-399 $\mu \mathrm{M}$, we were able to identify compounds with low-micromolar inhibitory potencies (IC50 values $0.5-14 \mu \mathrm{M}$ for compounds 5, 6,11 , and 27), indicating that a well-chosen covalent warhead might be able to cause a drastic increase in potency even with a non-optimized scaffold. The inhibitory potencies for all enzyme inhibitors in this manuscript are expressed as IC50 values (Table 1), although the compounds are in most cases irreversible. The IC50values are therefore dependent on the assay conditions and particularly on the pre incubation period. Despite these limitations, the measured IC50 values still allow relatively simple comparison sof compounds within a series. However, additional methods were used in all cases to provide further information about the enzymeinhibitor interactions. The covalent binding of the active compounds was confirmed by MS/MS studies, revealing that compounds 11 and 24 form covalent bonds with Cys115located in the active site of MurA (Figure S2 and Table S2).Furthermore, STD NMR measurements were also performed to confirm the binding of fragments 6, 7 and 27 to MurA(Figure S3). 


\begin{tabular}{|c|c|c|c|c|c|}
\hline & $\begin{array}{l}\mathrm{IC}_{50}[\mu \mathrm{M}] \\
\text { MurA }\end{array}$ & MAO-A & MAO-B & HDAC8 & $\mathrm{iCP} \beta 5 \mathrm{i}$ \\
\hline 1 & $164 \pm 14$ & N.A. & N.A. & N.A. & N.A. \\
\hline 2 & $264 \pm 23$ & N.A. & N.A. & $24.42 \pm 8.94$ & $18.50 \pm 9.19$ \\
\hline 3 & N.A. & N.A. & N.A. & $13.22 \pm 3.90$ & N.A. \\
\hline 4 & N.A. & $61.2 \pm 9.0$ & N.A. & $>50$ & N.A. \\
\hline 5 & $1.5 \pm 0.2$ & $0.34 \pm 0.01$ & $52.5 \pm 10.7$ & $0.51 \pm 0.05$ & $0.43 \pm 0.53$ \\
\hline 6 & $11 \pm 2.0$ & $4.04 \pm 0.24$ & N.A. & $0.03 \pm 0.01$ & N.A. \\
\hline $\begin{array}{l}7 \\
8\end{array}$ & $\begin{array}{l}107 \pm 11 \\
\text { N.A. }\end{array}$ & $\begin{array}{l}16.4 \pm 2.0 \\
116.1 \pm 22.8\end{array}$ & $\begin{array}{l}23.6 \pm 1.2 \\
58.9 \pm 3.9\end{array}$ & $\begin{array}{l}4.00 \pm 0.76 \\
16.65 \pm 6.78\end{array}$ & $\begin{array}{l}60.50 \pm 3.53 \\
\text { N.A. }\end{array}$ \\
\hline 10 & $339 \pm 31$ & N.A. & $95.0 \pm 9.0$ & $34.96 \pm 7.45$ & N.A. \\
\hline 11 & $13 \pm 2.7$ & $9.65 \pm 1.53$ & N.A. & $6.11 \pm 1.78$ & $5.90 \pm 2.50$ \\
\hline 12 & $97 \pm 10$ & $13.53 \pm 2.42$ & N.A. & $1.95 \pm 0.34$ & $25.50 \pm 17.68$ \\
\hline 15 & $381 \pm 29$ & $7.60 \pm 1.84$ & N.A. & $4.56 \pm 0.40$ & $12.50 \pm 12.02$ \\
\hline 21 & $76 \pm 8$ & $314 \pm 74$ & N.A. & $>50$ & N.A. \\
\hline 24 & $53 \pm 7$ & N.D. & N.D. & $1.02 \pm 0.12$ & $18.00 \pm 8.0$ \\
\hline 27 & $14 \pm 3$ & $113 \pm 29$ & N.A. & N.A. & $5.00 \pm 2.82$ \\
\hline
\end{tabular}

\section{Profiling on monoamine oxidases}

Monoamine oxidases $\mathrm{A}$ and $\mathrm{B}$ (MAO-A and MAO-B) are isoenzymes that catalyze oxidative deamination of mono-amines. Known covalent inhibitors bind to the flavin adenine dinucleotide (FAD) cofactor. Notably, Cys321 and Cys323 inMAO-A and Cys172 in MAO-B, which are located in the active site or in close vicinity, could be targeted by electrophiles.[17]Activity profiling demonstrated that several fragments inhibited both enzymes, whereas some selectively targeted only one isoform (Table 1). We identified low micromolar MAO-A inhibitors $(4,6,11,12,15,21$, and 27) with IC50values in the range of 4.0-314.0 - M, with no inhibition of MAO-B, and only one selective inhibitor of MAO-B (propiolate 10). Maleimide 5 was active on both isoforms, favoring MAO-A (IC50=0.3 - M) overMAO-B (IC50=52.5 - M). A detailed kinetic study revealed time-dependent and irreversible inhibition of fragments 6, 11, 12,and 15 (Figures S4 and S5). The covalent binding to MAO-A was confirmed by MS/MS proteomics, where vinyl sulfone 12formed a covalent bond with Cys321 and Cys323 (Figure 2,more details in Figure S6 and Table S3). To the best of our knowledge, these are the first experimentally confirmed covalent fragments that bind to a specific cysteine and not to theFAD cofactor of MAO-A. Profiling on HDAC8Histone deacetylase 8 (HDAC8) is an enzyme that plays a critical role in cell cycle progression by catalyzing the deacetylation of histones and a number of cytosolic proteins.[18]Considering the effects on cell reproduction, HDAC8 has attracted significant attention in oncology.[19]Numerous active fragments were identified in the HDAC8 inhibition screening (Figure S1). IC50values were determined for 11 active hits (Table 1). Notably, the acrylamide was clearly preferred in a more sterically hindered orientation, as 7 (IC50=4.0 - M) outperformed 1, whereas the other acrylic fragment pair, esters 2 (IC50=24.4 - M) and 8(IC50= $16.7 \cdot \mathrm{M})$, showed a similar potency. Maleimides were the only fragments active in the submicromolar range (IC50values of 0.5 and $0.03 \cdot M$ for 5 and 6, respectively). The potencies of the other nine compounds were in the low-micromolar range(Table 1). In addition, the time dependency of inhibition was shown for the four most potent fragments (i.e., maleimides 5 and 6 , vinylsulfone 12, and haloacetophenone 24; Figure S7).The site of labelling was determined by MS/MS after trypticdigestion of the labelled protein samples with the most active compounds 5, 6, and 24. Maleimides 5 and 6 were anchored tocysteines 244 and 275, while haloacetophenone 24 labelledCys275 only (Figure S8 and Table S4). Cys275 is in the proximity of the active site and its labelling might affect substrate binding, while fragments binding to Cys244 can be considered as allosteric modulators.[20]The broad activity profile obtained for this target 
suggests that the reactivity of the available cysteines in HDAC8 allows the use of a wide range of warhead chemotypes.

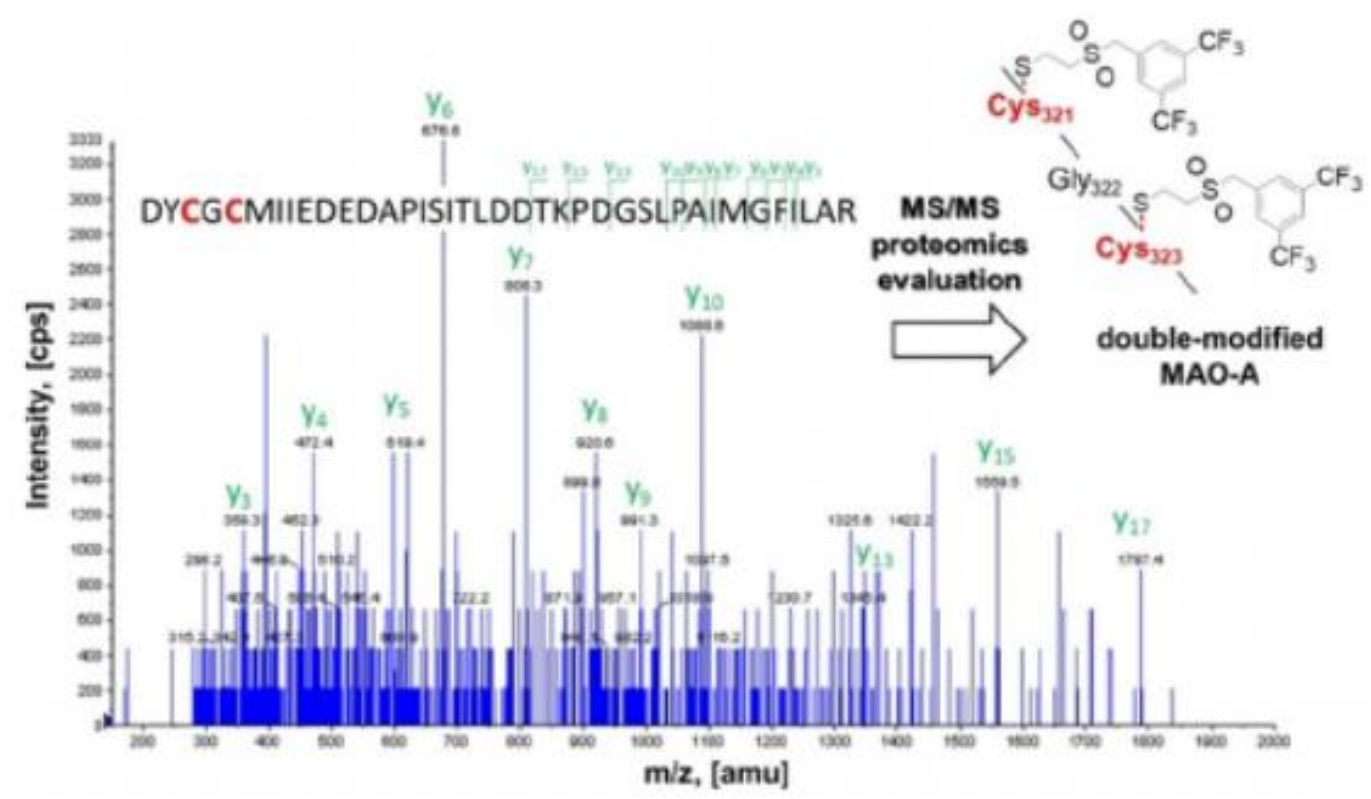

Figure 2. The MS/MS spectra of the enzyme-digested MAO-A peptide modified by covalent fragment 12 and the identified adduct

\section{Profiling on immunoproteasome (iCP)}

The immunoproteasome (iCP) is an isoform of the proteasome that is found mainly in cells of haematopoietic origin. Whereas the constitutive proteasome is a validated pharmacological target, individual subunits of the iCP are still being established as such.[21]Given that only a few inhibitors of the iCP are known ,there is a need for novel chemical starting points. We found a lower number of hits in the case of the $\cdot 5 i$ subunit of the iCPthan in other cases (Figure S1). Eight fragments were characterized in terms of their IC50values (Table 1), that is, the highly GSH-active chemotypes, including acrylester 2, maleimide 5,vinyl sulfones 11 and 12, benzyl isothiocyanate 15 , and haloacetophenone 24 . The most potent was maleimide (IC50=0.4 - M), while the IC50values of the remaining compounds were found to be within a 5.0-25.5 $-\mathrm{M}$ range. Similar to HDAC8, acrylamide 7 was identified as active (IC50=60.5 $\cdot$ M), whereasits structural pair acrylamide 1 did not show inhibition. Inaddition, intact MS measurements proved the covalent labelling with fragment 12 (Figure S9).

\section{Profiling on KRASG12C oncogen mutant}

KRAS is part of the RAS protein family of membrane-bound GTPases, which act as molecular switches. Somatic KRAS mutations are found in several cancers, with G12C (KRASG12C)being one of the most common mutations. Targeting Cys12 in the KRAS switch II pocket with covalent inhibitors represents a method of achieving selectivity over the wild-type protein to minimize toxicity.[22]The labelling efficiency of library members was investigated by Ellman's assay[23]as a direct estimation of the remaining free Cys ratio after incubating with the fragments(Figure 3). As KRASG12Chas four cysteine residues, theoretically25\% labelling ratio could be measured by complete and selective binding to the targeted Cys12. Therefore, we 
decided to set the labelling ratio (LR\%) limit for 25\%, which resulted in13 hits, including acrylic compounds 1, 2, 4 and 7, maleimides 5and 6, propiolate 10, vinyl sulfones 11 and 12,

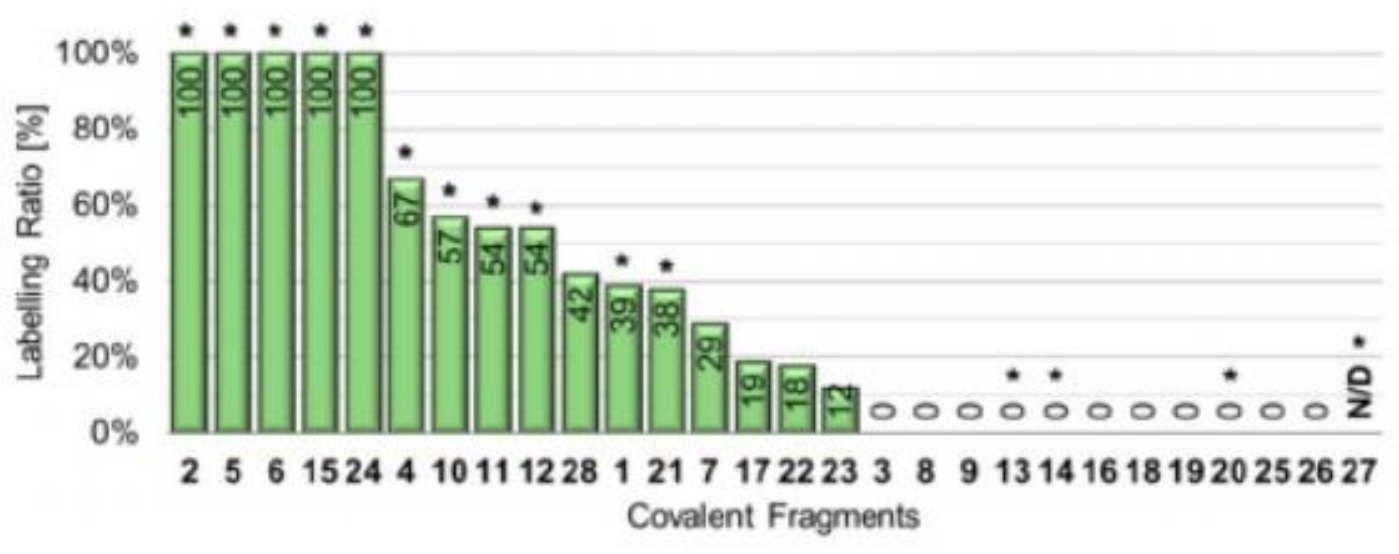

Figure 3. Results of Ellmann's assay and NMR measurements of KRASG12C. The Ellmann's assay results are presented as labelling ratio, the percentage efficacy ratio of the labelling. The covalent modifications confirmed by NMR measurements are indicated with a star on the top of the corresponding bar. N/D: not determined due to assay interference.

isothiocyanate 15 , haloacetamide 21 , haloacetophenone 24 , and aldehyde 28 . Because the Ellman's assay did not provide specific information on the labelling site, the compounds were subjected to 19F-NMR and 15N-HSQC NMR measurements to confirm covalent binding and identify the labelled residue (Figures S9 and S10). This methodology provided quick proof of the binding by compar-ing the $19 \mathrm{~F}$ shifts of the fragment in buffer as a reference with the fragment incubated with the protein. By comparing the results of both NMR methods, we found an almost perfect agreement between the more sophisticated 15N-HSQC measure-ments and the 19F-NMR protocol. There were only four outliers, that is, vinyl sulfonamide 13 , isothiocyanate 14 , and cyanamide 20, which were determined to be inactive in the Ellman's assay, but were proven to covalently label KRASG12C. Acrylamide 7 and aldehyde 28 were inactive in the NMR screen; however, these compounds showed labelling in the Ellman's assay. In every case where 19FNMR experiments showed binding, we were able to confirm the labelling by the $15 \mathrm{~N}-\mathrm{HSQC}$ experiment. This observation suggests 19F-NMR as an alternative to MS in cysteine mapping experiments with our library. In the case of KRASG12C, covalent labelling took place at Cys12 in all cases, with some compounds also labelling Cys118 as well.

\section{Conclusion}

To conclude, we report here the development of an electrophilic fragment library useful for the experimental evaluation of the accessibility and reactivity of cysteines, tractable for covalent inhibition. The wide range of thiol reactivity and high cysteine specificity of the fragments allowed us investigating a functionally and structurally diverse set of enzymes.

We confirmed that this methodology covers a wide range of targets. Furthermore, covalent binding was demonstrated with all enzymes that suggested particular warheads for developing specific TCIs. In the case of MAO-A, this analysis additionally revealed a new covalent 
mechanism of inhibition by binding to the non-catalytic Cys321 and Cys323. Our results support the notion that there is no universal warhead available for different targets. In fact, the required specificity of TCIs necessitates not only optimized noncovalent interactions but also careful selection and tailoring of warheads. We suggest that warhead profiling by the approach presented here should constitute an important initial step in the identification of optimal warheads and development of TCIs.

\section{Experimental Section}

\section{GSH reactivity and aqueous stability assay:[12a]}

For glutathione eassay 500 - M solution of the fragment (PBS buffer pH 7.4, 10\%acetonitrile, $250 \mu \mathrm{L}$ ) with $200 \cdot \mathrm{M}$ solution of indoprofen as interna lstandard was added to $10 \mathrm{mM}$ glutathione solution (dissolved inPBS buffer, $250 \mu \mathrm{L}$ ) in $1: 1$ ratio. The final concentration was $250 \mu \mathrm{M}$ fragment, $100 \mu \mathrm{M}$ indoprofen, $5 \mathrm{mM}$ glutathione and $5 \%$ acetonitrile $(500 \mu \mathrm{L})$. The final mixture was analysed by HPLC-MSafter $0,1,2,4,8,12,24,48,72 \mathrm{~h}$ time intervals. In the case of fragments that were not detectable in a concentration of $250 \mu \mathrm{M}$, the final concentrations were reversed, as $5 \mathrm{mM}$ for the fragment and $250 \mu \mathrm{M}$ for GSH. Degradation kinetics was also investigated respectively using the previously described method, applying pure PBS buffer instead of the glutathione solution. In this experiment the final concentration of the mixture was $250 \mu \mathrm{M}$ fragment, $100 \mu \mathrm{M}$ indoprofen and $5 \%$ acetonitrile. The AUC (area under the curve) values were determined via integration of HPLC spectra then corrected with internal standard. The fragments AUC values were applied for ordinary least squares (OLS) linear regression and for computing the important parameters (kinetic rate constant, half-lifetime) a programmed excel (Visual Basic for Applications) was used. The data are expressed as means of duplicate determinations, and the standard deviations were within $10 \%$ of the given values.The calculation of the kinetic rate constant for the degradation and corrected GSH-reactivity is the following. Reaction half-life for pseudo-first order reactions is $t 1 / 2=\ln 2 / k$, where $k$ is the reaction rate. In the case of competing reactions (reaction with GSH and degradation), the effective rate for the consumption of the starting compound is keff=kdeg+kGSH. When measuring half-lives experimentally, the $t 1 / 2$ (eff) $=\ln 2 / \mathrm{keff}=\ln 2 /(\mathrm{kdeg}+\mathrm{kGSH})$. In our case, the corrected kdeg and keff(regarding to blank and GSH containing samples, respectively) can be calculated by linear regression of the data points of the kinetic measurements. The corrected kGSHis calculated from keff - kdeg, and finally half-life time is determined using the equation $\mathrm{t} 1 / 2(\mathrm{GSH})=\ln 2 / \mathrm{kGSH}$.

\section{Oligopeptide selectivity assay:[12a]}

For nonapeptide assay $2 \mathrm{mM}$ solution of the fragment (PBS buffer $\mathrm{pH} 7.4$ with 20\% acetonitrile)was added to $200 \mu \mathrm{M}$ nonapeptide solution (PBS buffer $\mathrm{pH} 7.4$ ) in1:1 ratio. The final assay mixture contained $1 \mathrm{mM}$ fragment, $100 \mu \mathrm{M}$ peptide and $10 \%$ acetonitrile. The samples were incubated at room temperature overnight. Based on the GSH reactivity the applied incubation time was 16 or $24 \mathrm{~h}$. Fragments with less than $12 \mathrm{~h}$ half-life time against GSH were incubated for $16 \mathrm{~h}$, the others for $24 \mathrm{~h}$. Information-dependent acquisition (IDA) LC-MS/MS experiment was used to identify, whether the fragment binding was specific to thiol residues or not. Enhanced MS scan was applied as survey scan and enhanced product ion (EPI) was the 
dependent scan. The collision energy in EPI experiments was set to $30 \mathrm{eV}$ with collision energy spread (CES) of $10 \mathrm{~V}$. The identification of the binding position of the fragments to the nonapeptide was performed by GPMAW 4.2. software. Relative quantitation of the nonapeptidefragment covalent conjugates was calculated from the total ion chromatograms (based on peak area of the selected ion chromatograms).

\section{MurA biochemical assay:[24]}

MurA protein was recombinant, ex-pressed in E. coli. The inhibition of MurA was monitored with thec olorimetric malachite green method in which orthophosphate generated during reaction is measured. MurA enzyme (E. coli) was pre-incubated with the substrate UDP-Nacetylglucosamine (UNAG) and compound for $30 \mathrm{~min}$ at $37^{\circ} \mathrm{C}$. The reaction was started by the addition of the second substrate PEP, resulting in a mixture with final volume of $50 \mu \mathrm{L}$. The mixtures contained: 50 mM HEPES, pH 7.8, 0.005\% Triton X-114, $200 \mu \mathrm{M}$ UNAG, $100 \mu \mathrm{M}$ PEP, purified MurA (diluted in $50 \mathrm{mM}$ HEPES, $\mathrm{pH}$ 7.8) and $500 \mu \mathrm{M}$ of each tested compound dissolved in DMSO. All compounds were soluble in the assay mixtures containing $5 \%$ DMSO (v/v). After incubation for $15 \mathrm{~min}$ at $37{ }^{\circ} \mathrm{C}$, the enzyme reaction was terminated by adding Biomol@ reagent $(100 \mu \mathrm{L})$ and the absorbance was measured at $650 \mathrm{~nm}$ after $5 \mathrm{~min}$. Residual activities (RAs) were calculated with respect to similar assays without the tested compounds and with $5 \%$ DMSO. The IC50 values were determined by measuring the residual activities at seven different compound concentrations. The data are expressed as means of duplicate determinations, and the standard deviations were within $10 \%$ of the given values.

\section{STD NMR of MurA:}

The 1H STD NMR spectra were recorded on Bruker Avance Neo $600 \mathrm{MHz}$ (NMR Center, National Institute of Chemistry, Slovenia), using cryoprobe, at $25^{\circ} \mathrm{C}$. The pulse sequences provided in the Bruker library of pulse programmes were used. The samples were prepared in $90 \%$ D20/10\% [D6]DMSO buffer containing $20 \mathrm{mM}$ [D11]Tris, $150 \mathrm{mM} \mathrm{NaCl}$, and $0.049 \mathrm{mM}$ [D10] dithiothreitol; pD 7.4. Substrate UNAG was added at an enzyme/ substrate ratio of $1: 5$. All the spectra were recorded at an enzyme/ ligand ratio of 1: 100 . The enzyme concentration was $0.004 \mathrm{mM}$, and the ligand concentration was $0.4 \mathrm{mM}$.

STD experiments were performed with a $6250 \mathrm{~Hz}$ spectral width, 16.384 data points, a saturation time of $2 \mathrm{~s}$, a relaxation delay of $2 \mathrm{~s}$, and 480 scans. Selective saturation was achieved by a train of $50 \mathrm{~ms}$ long Gauss-shaped pulses separated by a $1 \mathrm{~ms}$ delay. Water was suppressed by excitation sculpting. The on-resonance selective saturation of the enzyme was applied at 0.42 $\mathrm{ppm}$. The off-resonance irradiation was applied at $30 \mathrm{ppm}$ for the reference spectrum.

\section{Protein labelling for MurA MS/MS proteomics:[12a]}

For the MurA labelling experiment the $42 \mu \mathrm{M}$ stock solution of MurA in 20 mM HEPES at pH 7.27.4 with $1 \mathrm{mM}$ DTT was filtered through a G25 column and the medium was changed to $50 \mathrm{mM}$ Tris with $0.005 \%$ Triton X-100 at pH 8.0. For the activation of the enzyme 1 mg UDPNAG was added as a solid to reach $40 \mathrm{mM}$ concentration and the mixture was incubated at $37{ }^{\circ} \mathrm{C}$ for 30 min. Fragments were added from a $250 \mathrm{mM}$ DMSO stock diluted in the labelling solution to 5 
$\mathrm{mM}$. The incubation was continued at $37^{\circ} \mathrm{C}$ for additional $30 \mathrm{~min}$. After the labelling, the mixture was purified on a G25 column.

\section{MAO-A and MAO-B biochemical assay:}

The effects of the test compounds on MAO-A and MAO-B were investigated using a fluorimetric assay, following a previously described literature method.[25] The inhibitory potency of the compounds was evaluated by their effects on the production of hydrogen peroxide (H2O2) from p-tyramine. The production of the $\mathrm{H} 2 \mathrm{O} 2$ was detected using Amplex Red reagent in the presence of horseradish peroxidase, where a highly sensitive fluorescent product, resorufin, is produced at stoichiometric amounts. Recombinant human microsomal MAO-A and MAO-B enzymes expressed in baculovirus-infected insect cells (BTI-TN-5B1-4), horse-radish peroxidase (type II, lyophilised powder), and p-tyramine hydrochloride were obtained from Sigma Aldrich. 10Acetyl-3,7-dihydroxyphenoxazine (Amplex Red reagent) was synthesised as described in the literature.[26]

Briefly, $100 \mu \mathrm{L} 50 \mathrm{mM}$ sodium phosphate buffer (pH 7.4, 0.05\% [v/v] Triton X-114) containing the compounds and MAO-A/B were incubated for 30 min at $37{ }^{\circ} \mathrm{C}$ in a flat-bottomed black 96well microplate. After the pre-incubation (30 min for the screening), the eaction was started by adding the final concentrations of $200 \mu \mathrm{M}$ Amplex Red reagent, $2 \mathrm{U} / \mathrm{mL}$ horseradish peroxidase, and $1 \mathrm{mM}$ p-tyramine (final volume, $200 \mu \mathrm{L}$ ). The production of resorufin wasquantified on the basis of the fluorescence generated $(\lambda \mathrm{ex}=530 \mathrm{~nm}, \lambda \mathrm{em}=590 \mathrm{~nm})$ at $37^{\circ} \mathrm{C}$ over a period of $30 \mathrm{~min}$, during which time the fluorescence increase linearly. For control experiments, DMSO was used instead of the appropriate dilutions of the compounds in DMSO. To determine the blank value (b), phosphate-buffered solution replaced the enzyme solution. The initial velocities were calculated from the trends obtained, with each measurement carried out in duplicate. The specific fluorescence emission to obtain the final result was calculated after subtraction of the blank activity (b). The inhibitory potencies are expressed as the residual activities (RA = (vib)/(vo-b), where vi is the velocity in the presence of the test compounds, and v0 the control velocity in the presence of DMSO. The IC50values were calculated) using GraphPad Prismv8.0 software. The results are mean \pm SEM of three independent experiments, each performed in duplicate. For determination of time-dependency, MAO-A was pre-incubated with the fragments for 5, 15 and $30 \mathrm{~min}$ and the assay was performed as described above. For the reversibility assay, MAO-A at 100-fold final concentration was incubated with the fragments at a concentration tenfold theIC50at $37^{\circ} \mathrm{C}$ (volume, 50 - L). After $30 \mathrm{~min}$, the mixture was diluted100-fold into the reaction buffer containing Amplex Red reagent, horseradish peroxidase, and p-tyramine hydrochloride. The final concentrations of all of the reagents and MAO-A were the same as in the assay described above. The reaction was monitored for $30 \mathrm{~min}$. Control experiments were carried out in the same manner, where the inhibitor solution was replaced by DMSO. Clorgyline and harmaline were used as control irreversible and reversible MAO-A inhibitors, respectively. The results are mean $\pm S D$ of three independent experiments, each performed in quadruplicate

\section{Protein labelling for MAO-A MS/MS proteomics:}

Human recombi-nant MAO-A (52 mM nominal concentration) in $50 \mathrm{mM}$ sodiumphosphate buffer at pH 7.8 together with $300 \mathrm{mM} \mathrm{NaCl}, 20 \mathrm{mM}$ imidazole, $0.05 \%$ FOS-choline- 12 and 40\% glycerol was used for the labelling. The enzyme was expressed in Pichia pastoris and purified 
following published protocols.[27]The MAO-A sample was quickly thawed from $-78^{\circ} \mathrm{C}$ to $37^{\circ} \mathrm{C}$, and centrifuged ( $5 \mathrm{~min}$ at $7500 \mathrm{~g}$ ) in order to remove the aggregated protein. MAO-A was buffer exchanged to $50 \mathrm{mM} \mathrm{K3PO4at} \mathrm{pH} 7.5$ together with $0.25 \%$ Triton X-100[28] and stored on ice. The electrophilic fragments were added in $0.5 \mu \mathrm{L}$ DMSO $(100 \mathrm{mM})$ to a $35-50 \mu \mathrm{L}$ of the enzyme solution to reach 35 - to 50 -fold excess of the fragments. The samples were incubated at $4^{\circ} \mathrm{C}$ for $24 \mathrm{~h}$.

\section{HDAC8 biochemical assay:}

Enzyme activity assay was executed in assay buffer $(25 \mathrm{mM}$ Tris $\cdot \mathrm{HCl} \mathrm{pH} 8.0,50 \mathrm{mM} \mathrm{NaCl}$ and $0.001 \%$ (v/v)P luronic F-68) in black half area 96-well microplates (Greiner Bio-One, Germany). For the initial screening $10 \mathrm{nM}$ HDAC8 was pre-incubated with $250 \mu \mathrm{M}$ of the indicated compounds for $2 \mathrm{~h}$ at $30^{\circ} \mathrm{C}$. For IC50determination $10 \mathrm{nM}$ HDAC8 was pre-incubated with a serial dilution of the indicated compounds for $1 \mathrm{~h}$ and with varying times for the time dependent IC50curves. The enzyme reaction was initiated by the addition of 20 - M Boc-Lys(TFA)$\mathrm{AMC}\left(\right.$ Bachem, Switzerland). After substrate conversion at $30^{\circ} \mathrm{C}$ for $1 \mathrm{~h}$ the reaction was stopped by adding $1.67 \mu \mathrm{M}$ suberoylanilidetrifluoromethylketone (SATFMK). For time dependent IC50measure-ments the substrate conversion was stopped after $5 \mathrm{~min}$. Thedeacetylated substrate was cleaved with $0.42 \mathrm{mg} / \mathrm{mL}$ trypsin to release fluorescent 7-amino-4methylcoumarin (AMC), which was detected with a microplate reader (PHERAstar FS or BMG LABTECH) with fluorescence excitation at $360 \mathrm{~nm}$ and emission at $460 \mathrm{~nm}$. IC50values were calculated by generating dose-response curves in GraphPad Prism 6 and fitting those to a fourparameter logistic model.

\section{Protein labelling for HDAC8 MS/MS proteomics:}

For covalent labelling $25 \mu \mathrm{M}$ HDAC8 was treated with $250 \mu \mathrm{M}$ of the indicated compound for $1 \mathrm{~h}$ at $30{ }^{\circ} \mathrm{C}$ in assay buffer as described above. After reaction the protein was precipitated by the addition of $10 \%$ TCA and afterwards centrifuged at $18000 \mathrm{~g}$ for $15 \mathrm{~min}$. The supernatant was removed, and dry pellet was diluted in buffer (50 mM NH4HCO3, pH 7.8).

\section{Immunoproteasome ( $\beta 5 i)$ biochemical assay:}

The screening of compounds was performed at $100 \mu \mathrm{M}$ final concentrations in assay buffer $(0.01$ \% SDS, $50 \mathrm{mM}$ Tris $\cdot \mathrm{HCl}, 0.5 \mathrm{mM}$ EDTA, $\mathrm{pH}$ 7.4). To each electrophilic fragment, $0.2 \mathrm{nM}$ human iCP (Boston Biochem, Inc., Cambridge/MA, USA) was added and incubated for $30 \mathrm{~min}$ at $37^{\circ} \mathrm{C}$. Afterwards, the reaction was initiated by the addition of Suc-LLVY-AMC (a substrate to evaluate the activity of the $\beta 5 \mathrm{i}$ subunit of the immunoproteasome, Bachem, Bubendorf, Switzerland) at 25 $\mu \mathrm{M}$ final concentration. The reaction progress was recorded on the BioTek Synergy HT microplate reader by monitoring fluorescence at $460 \mathrm{~nm}(\lambda \mathrm{ex}=360 \mathrm{~nm})$ for $90 \mathrm{~min}$ at $37^{\circ} \mathrm{C}$. The initial linear ranges were used to calculate the velocity and to determine the residual activity. The results are means from at least three independent measurements. Standard errors for RAs were less than $15 \%$ in every case.

Compounds that showed average residual activity below $50 \%$ in the RA determination assay were initially dissolved in DMSO, and then added to black 96 -well plates in the assay buffer 0.01 $\%$ SDS, $50 \mathrm{mM}$ Tris-HCl, $0.5 \mathrm{mM}$ EDTA, $\mathrm{pH}$ 7.4) to obtain eight different final concentrations. The inhibitors were pre-incubated with $0.2 \mathrm{nM}$ human iCP (Boston Biochem, Inc., Cambridge/MA, USA) at $37^{\circ} \mathrm{C} 30 \mathrm{~min}$, before the reaction was initiated by the Suc-LLVY-AMC substrate (Bachem, 
Bubendorf, Switzerland). The fluorescence was monitored at $460 \mathrm{~nm}(\lambda \mathrm{ex}=360 \mathrm{~nm})$ for $90 \mathrm{~min}$ at $37^{\circ} \mathrm{C}$. The progress of the reactions was recorded and the initial linear ranges were used to calculate the velocity. IC50 values were calculated in Prism (GraphPad Software, CA, USA) and are means from at least three independent determinations.

\section{Protein labeling for immunoproteasome ( $\beta 5 i)$ MS analysis:}

For the immunoproteasome labelling experiments, isolated $\beta 5 \mathrm{i}$ subunit was purchased from ProSpec-Tany TechnoGene Ltd, as $22 \mu \mathrm{M}$ solution in $20 \mathrm{mM}$ Tris-HCl buffer ( $\mathrm{pH}$ 8.0), with $0.4 \mathrm{M}$ urea and $10 \%$ glycerol. The peptide solution was filtered through a G25 column and the medium was changed to $50 \mathrm{mM}$ Tris (pH 7.4) with $0.5 \mathrm{mM}$ EDTA and $0.01 \%$ SDS. Fragments were added from a $100 \mathrm{mM}$ DMSO stock diluted in the labelling solution to $1 \mathrm{mM}$. The samples were kept at $37^{\circ} \mathrm{C}$ for $5 \mathrm{~h}$, then at room temperature for further $12 \mathrm{~h}$. Finally, the samples were purified on a G25 column.

\section{MS analysis of the labelled immunoproteasome ( $\beta 5 i)$ :}

The molecular weights of the conjugates of IPS B5i were identified using a Triple TOF $5600+$ hybrid Quadrupole-TOF LC/MS/MS system (Sciex, Singapore, Woodlands) equipped with a DuoSpray IonSource coupled with a Shimadzu Prominence LC20 UFLC (Shimadzu, Japan) system consisting of binary pump, an autosampler and a thermostated column compartment. Data acquisition and processing were performed using Analyst TF software version 1.7.1 (AB Sciex Instruments, CA, USA). Chromatographic separation was achieved on a Thermo Beta Basic C8 ( $50 \mathrm{~mm} \times 2,1 \mathrm{~mm}, 3 \mu \mathrm{m}, 150 \AA$ ) HPLC column. Sample was eluted in gradient elution mode using solvent A (0.1\% formic acid in water) and solvent B (0.1\% formic acid in ACN). The initial condition was $20 \%$ B for $1 \mathrm{~min}$, followed by a linear gradient to $90 \%$ B by $4 \mathrm{~min}$, from 5 to $6 \mathrm{~min}$ $90 \%$ B was retained; and from 6 to 6.5 min back to initial condition with $20 \%$ eluent B and retained from 6.5 to $9.0 \mathrm{~min}$. Flow rate was set to $0.4 \mathrm{ml} / \mathrm{min}$. The column temperature was $40^{\circ} \mathrm{C}$ and the injection volume was $5 \mu \mathrm{l}$. Nitrogen was used as the nebulizer gas(GS1), heater gas (GS2), and curtain gas with the optimum values set at 30, 30 and 35 (arbitrary units), respectively. Data were acquired in positive electrospray mode in the mass range of $\mathrm{m} / \mathrm{z} 300$ to 2500 , with $1 \mathrm{~s}$ accumulation time. The source temperature was $350^{\circ} \mathrm{C}$ and the spray voltage was set to 5500 V. Declustering potential value was set to 80 V. Peak View Software TM V.2.2(version 2.2, Sciex, Redwood City, CA, USA) was used for deconvoluting the raw electrospray data to obtain the neutral molecular masses.

\section{Digestion and proteomics MS/MS analysis:[12a]}

After the labelling40-50 $\mu \mathrm{L}$ of the sample and $10 \mu \mathrm{L} 0.2 \%$ (w/v) RapiGest SF (Waters, Milford, USA) solution buffered with $50 \mathrm{mM}$ ammonium bicarbonate were mixed (pH 7.8) and $3.3 \mu \mathrm{L}$ of $45 \mathrm{mM}$ DTT in $100 \mathrm{mMNH} 4 \mathrm{HCO3were}$ added and kept at $37.5^{\circ} \mathrm{C}$ for $30 \mathrm{~min}$. After coolingthe sample to room temperature, $4.16 \mu \mathrm{L}$ of $100 \mathrm{mM}$ iodoacetamidein $100 \mathrm{mM}$ NH4HCO3were added and placed in the dark in room temperature for $30 \mathrm{~min}$. The reduced and alkylated protein was then digested by $10 \mu \mathrm{L}(1 \mathrm{mg} / \mathrm{mL}$ ) trypsin (the enzyme/protein ratio was $1: 10$; Sigma). The sample was incubated at $37^{\circ} \mathrm{C}$ for overnight. To degrade the surfactant, $7 \mu \mathrm{L}$ of formic acid $(500 \mathrm{mM})$ solution was added to the digested protein sample to obtain the final40 $\mathrm{mM}$ concentration $(\mathrm{pH} \approx 2)$ and was incubated at $37^{\circ} \mathrm{C}$ for $45 \mathrm{~min}$. For LC-MS analysis, the acid treated sample was centrifuged for $5 \mathrm{~min}$ at $17000 \mathrm{~g}$. QTRAP 6500 triple quadruple-linear ion 
trap mass spectrometer, equipped with a Turbo V source in electrospray mode (AB Sciex, CA, USA) and a Perkin Elmer Series 200 micro LC system was used for LC-MS/MS analysis. Data acquisition and processing were performed using Analyst software version 1.6.2 (ABSciex Instruments, CA, USA). Chromatographic separation was achieved by using the Vydac 218 TP52 Protein \& Peptide C18column $(250 \mathrm{~mm} \times 2.1 \mathrm{~mm}, 5 \mu \mathrm{m})$. The sample was eluted with agradient of solvent $\mathrm{A}(0.1 \%$ formic acid in water $)$ and solvent $\mathrm{B}(0.1 \%$ formic acid in $\mathrm{ACN})$. The flow rate was set to $0.2 \mathrm{~mL} / \mathrm{min}$. The initial conditions for separation were $5 \% \mathrm{~B}$ for $7 \mathrm{~min}$, followed by a linear gradient to $90 \%$ B by $53 \mathrm{~min}$, from 60 to $63 \mathrm{~min} 90 \%$ B is retained; from 64 to $65 \mathrm{~min}$ back to the initial conditions with $5 \%$ eluent $\mathrm{B}$ retained to $70 \mathrm{~min}$. The injection volume was 10 $\mu \mathrm{L}$ (300pmol on the column). Information Dependent Acquisiton (IDA) LC-MS/MS experiment was used to identify the modified trypticpeptide fragments. Enhanced MS scan (EMS) was applied as survey scan and enhanced product ion (EPI) was the dependent scan. The collision energy in EPI experiments was set to rolling collision energy mode, where the actual value was set on the basis of themass and charge state of the selected ion. Further IDA criteria: ions greater than: $400.000 \mathrm{~m} / \mathrm{z}$, which exceeds106 counts, exclude former target ions for $30 \mathrm{~s}$ after 2 occurrences. In EMS and in EPImode the scan rate was $1000 \mathrm{Da} / \mathrm{s}$ as well. Nitrogen was used asthe nebulizer gas (GS1), heater gas (GS2), and curtain gas with the optimum values set at 50 , 40 and 40 (arbitrary units). The source temperature was $350^{\circ} \mathrm{C}$ and the ion spray voltage set at 5000 V. Declustering potential value was set to $150 \mathrm{~V}$. GPMAW 4.2 software and ProteinProspector[29] was used to analyse the large number ofMS-MS spectra and identify the modified tryptic peptides.

\section{KRASG12Canalysis by Ellman's assay:}

To measure thiol-reactivity, $2 \mu \mathrm{M}$ GDP-bound KRASG12Cin assay buffer ( $25 \mathrm{mM} \mathrm{NaH2P04,} 0.1$ mMEDTA, $150 \mathrm{mM} \mathrm{NaCl}, \mathrm{pH}$ 6.6) was treated with $200 \mu \mathrm{M}$ of fragments, resulting $5 \%$ DMSO concentration in the mixture. After $2 \mathrm{~h}$ of incubation on room temperature, $16 \mu \mathrm{L}$ of the sample was pipetted into a black, 384-well assay plate (Corning, Ref No.: 4514) and $4 \mu \mathrm{L}$ of thiol detection reagent (Invitrogen, ref no.: TC012-1EA) was added. After brief shaking, the plate was incubated in dark, room temperature for $30 \mathrm{~min}$, then fluorescence was measured in duplicates in a microplate reader (BioTek Synergy $\mathrm{Mx} ; \lambda \mathrm{ex}=390 \mathrm{~nm}$ and $\lambda \mathrm{em}=510 \mathrm{~nm}$ ). Free thiol ratio (FTR\%) labelling ratio (LR\%)values were calculated, as follows:

$$
\begin{aligned}
& \mathrm{FTR}[\%]=100 \bullet \frac{\mathrm{RFU}_{\text {sample }}-\mathrm{RFU}_{\text {background }}}{\mathrm{RFU}_{\text {DMSO }}-\mathrm{RFU}_{\text {background }}} \\
& \mathrm{LR}[\%]=100 \bullet \frac{\mathrm{RFU}_{\text {DMSO }}-\mathrm{RFU}_{\text {sample }}}{\mathrm{RFU}_{\text {DMSO }}-\mathrm{RFU}_{\text {background }}}
\end{aligned}
$$

\section{KRASG12C analysis by NMR:}

NMR measurements for testing binding BTF compounds to GDP-bound KRASG12C protein were carried out on a Bruker Avance III $700 \mathrm{MHz}$ spectrometer equipped with a 5-mm Prodigy TCI $\mathrm{H} \& \mathrm{~F} \mathrm{C} / \mathrm{N} \mathrm{D}$, z-gradient probe head operating at $700.05 \mathrm{MHz}$ for $1 \mathrm{H}$ and $70.94 \mathrm{MHz}$ for $15 \mathrm{~N}$ and $658.71 \mathrm{MHz}$ for $19 \mathrm{~F}$ nuclei. Spectra were recorded at $298 \mathrm{~K}$. TFA standard solution contained $0.1 \%$ trifuoroacetic acid in H2O. For NMR samples BTF compounds were dissolved in DMSO in $12 \mathrm{mM}$ concentration. To obtain reference spectra free BTF molecules (without protein) were measured in PBS buffer (pH 7.4), 5 mM MgCl2, 10 \% D2O and 5\% BTF-stock solution (in DMSO) 
and $0.2 \%$ TFA standard solution ( $1 \mu \mathrm{L}$ in $500 \mu \mathrm{L}$ NMR sample) and for the protein (without BTF molecules) were measured in 15N-labeled KRAS4B G12C(1-169) (catalytic do-main) mutant in $0.2 \mathrm{mM}$ concentration, $5 \mathrm{mM}$ GDP, $10 \mathrm{mM}$ EDTA, $15 \mathrm{mM} \mathrm{MgCl} 2$ in PBS buffer (pH 7.4), 10 \% D2O, $5 \%$ DMSO and $1 \%$ DSS standard. NMR samples for binding tests contained $15 \mathrm{~N}$-labeled KRAS4B G12C(1-169) in $0.2 \mathrm{mM}$ concentration, $5 \%$ BTF-stock sol-ution (in DMSO, the final concentration of the compound is $0.6 \mathrm{mM}$ ), 2-3 mM GDP, 3-5 mM EDTA, 8-10 mM MgCl2 in PBS buffer (pH 7.4), $10 \%$ D20 and 0.2\% TFA standard solution ( $1 \mu \mathrm{L}$ in $500 \mu \mathrm{L}$ NMR sample).

In binding tests 1D 19F-NMR (NS = 4), 1D 1H NMR (NS = 64) and 2D 1H,15N SOFAST HMQC (NS $=64$ ) spectra containing the very same information as $1 \mathrm{H}, 15 \mathrm{~N}-\mathrm{HSQC}$ spectra were performed subsequently immediately after mixing (i. e., 0.3-1 h) and after 1 day's incubation (22-28 h) at room temperature. In case of those BTF molecules which half lives in PBS + $5 \%$ DMSO buffer were shorter than $24 \mathrm{~h}$ according to HPLC measurements, the incubation time was a minimum of 10 times longer than the (estimated) half-life if shorter than 1 day. To obtain reference signals for free BTF molecules, 19F-NMR spectra were performed with the same parameters as in the binding test after a minimum of 3-4 half-life time incubation and for the free protein a 2D $1 \mathrm{H}, 15 \mathrm{~N}-\mathrm{SOFAST}$ HMQC spectrum was used. Sequence specific assignment of HN and NH in the bound KRASG12C spectra were transferred from previous results.[30] All 1H chemical shifts were referenced to the DMSO peaks (which were calibrated to DSS resonance before in free protein measurements) as DSS were not added to avoid any side reactions with the limited amount of small molecules. $15 \mathrm{~N}$ chemical shift values were referenced indirectly using the corresponding gyromagnetic ratios according to IUPAC convention. 19F chemical shifts were referenced to the TFA signal corresponding to its CF3 group. All spectra were processed with Bruker TOPSPIN. Binding was confirmed in every case by both 19F-NMR and 1H,15N-SOFAST HMQC spectra: based on the BTF compound evidenced by comparing 19F-NMR spectra of free BTF compound and BTF + protein and KRASG12Cdemonstrated by comparing $1 \mathrm{H}, 15 \mathrm{~N}$-SOFAST HMQC spectra of free KRASG12C-GDP and BTF + protein. Based on the assignment of $1 \mathrm{H}, 15 \mathrm{~N}-$ SOFAST HMQC spectra KRASG12C-GDP, the cysteines modified covalently by BTF molecules were determined as well.

\section{Syntheses}

\section{N-(3,5-Bis(trifluoromethyl)phenyl)acrylamide (1):[31]}

Triethylamine (1.40 mL, $10 \mathrm{mmol}$ ) was added to a solution of 3,5-bis (trifluoromethyl)aniline $(1.56 \mathrm{~mL}, 10 \mathrm{mmol})$ in $\mathrm{CH} 2 \mathrm{Cl} 2(30 \mathrm{~mL})$, and the mixture was allowed to stir under Ar at room temperature (RT)for $10 \mathrm{~min}$. The mixture was cooled with iced water and the nacryloyl chloride ( $0.81 \mathrm{~mL}, 10 \mathrm{mmol}$ ) was added dropwise, and the reaction was left to stir at RT for $2 \mathrm{~h}$. The reaction was concentrated under vacuum. The residue was diluted with $\mathrm{H} 2 \mathrm{O}$ and extracted with EtOAc. The organic layer was washed with $1 \mathrm{M}$ aq. $\mathrm{HCl}$, dried over $\mathrm{Na2SO}$, filtered, and concentrated under vacuum. The product was washed with Et2O and then vacuum dried to afford 1 as a white powder (2.06 g, 70\%).1H NMR (500 MHz, [D6]DMSO): $\delta=10.76$ (s, 1H, NH), $8.32(\mathrm{~s}, 2 \mathrm{H}, \mathrm{ArH}), 7.76(\mathrm{~s}, 1 \mathrm{H}, \mathrm{ArH}), 6.37$ (qd, J=17.0, $5.9 \mathrm{~Hz}, 2 \mathrm{H},=\mathrm{CH} \cdot$ ), $5.86 \mathrm{ppm}(\mathrm{dd}, \mathrm{J}=9.7$, $2.1 \mathrm{~Hz}, 1 \mathrm{H},=\mathrm{CH}-$ ) $.19 \mathrm{FNMR}(650 \mathrm{MHz}, \mathrm{D} 20): \delta=-62.7 \mathrm{ppm}$. 


\section{3,5-Bis(trifluoromethyl)phenyl acrylate (2):}

3,5-Bis(trifluoromethyl)phenol $(0.15 \mathrm{~mL}, 1 \mathrm{mmol})$ and $\mathrm{N}, \mathrm{N}$-diisopropylethylamine $(0.17 \mathrm{~mL}, 1$ mmol) were dissolved in $10 \mathrm{~mL} \mathrm{CH} 2 \mathrm{Cl} 2$, and the solution wasstirred at RT for $10 \mathrm{~min}$. The reaction mixture was cooled with icedwater, and then acryloyl chloride $(0.08 \mathrm{~mL}, 1 \mathrm{mmol})$ was addeddropwise. Then the reaction was allowed to stir at RT overnight.The solvent was removed under vacuum and the residue wasdissolved in ethyl acetate. The solution was washed with saturatedsodium bicarbonate and water. The organic phase was dried overNa2SO4, filtered, and concentrated under vacuum. The product waspurified by flash column chromatography using a mixture ofhexane and ethyl acetate as eluent. The compound 2 was obtainedas a colourless oil (39 mg, 14\%)1H NMR (300 MHz, CDCl3): $\delta=7.82(\mathrm{~s}, 1 \mathrm{H}, \mathrm{ArH}), 7.70(\mathrm{~s}, 2 \mathrm{H}, \mathrm{ArH}$ ), 6.72 (d, J = 17.2 $\mathrm{Hz}, 1 \mathrm{H},=\mathrm{CH}-), 6.39(\mathrm{dd}, \mathrm{J}=17.2,10.5 \mathrm{~Hz}, 1 \mathrm{H},=\mathrm{CH} 2), 6.16 \mathrm{ppm}(\mathrm{d}, \mathrm{J}=10.4 \mathrm{~Hz}, 1 \mathrm{H},=\mathrm{CH} 2) .13 \mathrm{C}$ NMR (75 MHz, CDCl3): $\delta=163.75,151.33,134.47,133.21$ (q,J= 34.1 Hz, 2 C), 127.12, 123.01 (d, J $=272.9 \mathrm{~Hz}, 2 \mathrm{C}$ ), 122.71 (2C),120.49-119.43 ppm (m).19F NMR (650 MHz, D2O): $\delta=-64.6$ ppm. Anal. calcd. for C11H6F6O2: C, 46.47; H, 2.11. found: C, 46.38; H, 2.15.

\section{3,5-Bis(trifluoromethyl)phenyl propionate (3):}

3,5-Bis(trifluoromethyl)phenol $(0.15 \mathrm{~mL}, 1 \mathrm{mmol})$, dicyclohexylcarbodiimide $(0.21 \mathrm{~g}, 1 \mathrm{mmol})$, $\mathrm{N}, \mathrm{N}$-dimethylaminopyridine $(1.2 \mathrm{mg}, 0.01 \mathrm{mmol})$ and propiolic acid (68 $\cdot \mathrm{L}, 1.1 \mathrm{mmol}$ ) were dissolved in $\mathrm{CH} 2 \mathrm{Cl} 2(5 \mathrm{~mL})$ at $0^{\circ} \mathrm{C}$, and stirred for $5 \mathrm{~h}$, the colourless solution turning to a yellow suspension. The reaction mixture was quenched with $20 \mathrm{~mL}$ of water and separated. The aqueous phase was extracted with dichloromethane $(2 \times 20 \mathrm{~mL})$. The organic phase was dried overMgSO4, filtered, and concentrated under vacuum. The product was purified by flash column chromatography using a mixture of hexane and ethyl acetate as eluent. Compound 3 was obtained as a white solid (40 mg, $14 \%$ ).1H NMR (500 MHz, [D6]DMSO): $\delta=8.14(\mathrm{~s}, 2 \mathrm{H}, \mathrm{ArH}$ ), 8.05 (s, 1H, ArH), $4.92 \mathrm{ppm}(\mathrm{s}, 1 \mathrm{H}, \equiv \mathrm{CH}) .13 \mathrm{C} \mathrm{NMR(125} \mathrm{MHz}$, [D6]DMSO): $\delta=150.7,150.5,132.1$ (q, J = 33.7 Hz, 2 C),124.2 (d, J= 3.8 Hz, 2 C), 123.1 (q, J= 271.3 Hz, 2 C), 120.8-121.0(m), 82.9, 74.2 ppm.19F NMR (650 MHz, D20): $\delta=-64.7$ ppm. Anal.calcd. for C11H4F6O2: C, 46.81; H, 1.42. found: C, $46.67 ; \mathrm{H}, 1.49$.

\section{3-(3,5-Bis(trifluoromethyl)phenyl)-2-cyanoacrylamide (4):}

[31]3,5-Bis(trifluoromethyl)benzaldehyde (0,33 mL, $2 \mathrm{mmol}$ ) and 2-cyanoaceta-mide (252 $\mathrm{mg}, 3$ mmol) were dissolved in methanol $(15 \mathrm{~mL})$. To this solution catalytic $\mathrm{NaOH}(1 \mathrm{mg}, 1 \%)$ was added, and the reaction was stirred at $45^{\circ} \mathrm{C}$ for $4 \mathrm{~h}$. The reaction was concentrated undervacuum, followed by adding $25 \mathrm{~mL}$ water and $25 \mathrm{~mL}$ ethyl acetate to the residue. After separation, the organic layer was washed with brine, dried over $\mathrm{Na2SO4}$, filtered, and concentrated under vacuum. The product was obtained as white powder (228 mg, $37 \%$ ) bycolumn chromatography with a mixture of hexane and ethylacetate as eluent.1H NMR (500 MHz, [D6]DMSO): $\delta=8.54(\mathrm{~s}, 2 \mathrm{H}, \mathrm{ArH}), 8.37(\mathrm{~s}, 1 \mathrm{H}, \mathrm{ArH}), 8.31(\mathrm{~s}, 1 \mathrm{H},=\mathrm{CH}-), 7.97(\mathrm{~s}, 1 \mathrm{H}$, NH2),7.89 ppm (s, 1H, NH2).19F NMR (650 MHz, D2O): $\delta=-62.7 \mathrm{ppm}$.

\section{1-(3,5-Bis(trifluoromethyl)phenyl)-1H-pyrrole-2,5-dione (5):[32]}

To a solution of maleic anhydride (214 mg, $2.18 \mathrm{mmol}$ ) in dichloromethane (20 mL) 3,5bis(trifluoromethyl)aniline $(0.34 \mathrm{~mL}, 2.2 \mathrm{mmol})$ was added dropwise at $40{ }^{\circ} \mathrm{C}$, and the mixture was allowed to stir for $2 \mathrm{~h}$. The intermediate was obtained as white crystals (705 mg, $98 \%$ ) and collected by filtration. The intermediate was dissolved in toluene $(30 \mathrm{~mL})$, then catalytical 
amount of $\mathrm{H} 2 \mathrm{SO} 4$ was added (1-2 drops). The reaction flask was equipped with a Dean-Stark apparatus and the mixture was refluxed at $130{ }^{\circ} \mathrm{C}$ for $3 \mathrm{~h}$. The solvent was removed under vacuum and the residue was purified by flash column chromatography with a mixture of hexane and ethyl acetate as eluent. The product was obtained as brown solid (272 mg, $40 \%) .1 \mathrm{H} \mathrm{NMR}$ (500 MHz, [D6]DMSO): $\delta=8.15(\mathrm{~s}, 1 \mathrm{H}, \mathrm{ArH}), 8.12(\mathrm{~s}, 2 \mathrm{H}, \mathrm{ArH}), 7.27 \mathrm{ppm}(\mathrm{s}, 2 \mathrm{H},=\mathrm{CH}-$ ). 19F NMR (650 MHz, D20): $\delta=62.7 \mathrm{ppm}$.

\section{1-(3,5-Bis(trifluoromethyl)benzyl)-1H-pyrrole-2,5-dione (6):}

The same procedure as for 5 except using 3,5-bis(trifluoromethyl)benzylamine (535 $\mathrm{mg}, 2.18$ mmol). The product was obtained as brown solid (317 mg, $45 \%$ ). 1H NMR (500 MHz, [D6]DMSO): $\delta=8.27(\mathrm{~s}, 2 \mathrm{H}, \mathrm{ArH}), 8.21(\mathrm{~s}, 2 \mathrm{H},-\mathrm{CH}=), 8.11(\mathrm{~s}, 1 \mathrm{H}, \mathrm{ArH}), 4.25 \mathrm{ppm}(\mathrm{d}, \mathrm{J}=5.2 \mathrm{~Hz}$, 2H, CH2). 13C NMR (125 MHz, [D6]DMSO): $\delta=172.5$ (2C), 137.7 (2C), 130.8 (2C), 130.7 (q, J = $32.5 \mathrm{~Hz}$ ), 130.6 (2C), 124.7, 122.5-122.7 (m, 2 C), 41.8 ppm. 19F NMR (650 MHz, D20): $\delta=62.5$ ppm. HRMS (ESI): [M +H]+ calcd. for C13H7F6NO2 +, 324.0459; found: 324.0447.

\section{3-(3,5-Bis(trifluoromethyl)phenyl)acrylamide (7):}

In a sealed tube 3,4-bis(trifluoromethyl)bromobenzene $(0.35 \mathrm{~mL}, 2 \mathrm{mmol})$, acrylamide $(171 \mathrm{mg}$, $2.4 \mathrm{mmol}), \mathrm{Pd}(\mathrm{OAc}) 2(11 \mathrm{mg}, 0.05 \mathrm{mmol})$, diisopropylethyl-amine $(0.42 \mathrm{~mL}, 2.4 \mathrm{mmol})$ and tri(otolyl)phosphine (30 mg, $0.1 \mathrm{mmol}$ ) was added to dimethylformamide (5 mL) under $\mathrm{Ar}$ and heated at $130{ }^{\circ} \mathrm{C}$ for $1.5 \mathrm{~h}$. The crude mixture was filtered from activated charcoal and water/MeOH 1: 1 was added. The forming yellow crystals were filtered (140 mg, $49 \%) .1 \mathrm{H} \mathrm{NMR}$ (500 MHz, CDCl3): $\delta=7.92$ (s, 2H, ArH), $7.86(\mathrm{~s}, 1 \mathrm{H}, \mathrm{ArH}), 7.70(\mathrm{~d}, \mathrm{~J}=15.7 \mathrm{~Hz}, 1 \mathrm{H},=\mathrm{CH}-$ ), 6.60 (d, J = $15.7 \mathrm{~Hz}, 1 \mathrm{H},=\mathrm{CH}-$ ), $5.71 \mathrm{ppm}(\mathrm{s}, 2 \mathrm{H}, \mathrm{NH} 2) .13 \mathrm{C}$ NMR (125 MHz, CDCl3): $\delta=166.3,138.3$, 136.3 (2C), 131.3 (q, J = 33.0 Hz), 128.4, 128.3, 127.1 (2C), 124.7, 122.5-122.8 ppm (m). 19F NMR (650 MHz, D20): $\delta=62.6$ ppm. HRMS (ESI): [M + H]+ calcd. for C11H7F6NO+ : 284.0510; found: 284.0509 .

\section{Ethyl 3-(3,5-bis(trifluoromethyl)phenyl)acrylate (8):[33]}

In a sealed tube $0.35 \mathrm{~mL} \mathrm{3,4-bis(trifluoromethyl)bromobenzene} \mathrm{(2} \mathrm{mmol),} \mathrm{ethylacry-late}(0.26$ $\mathrm{mL}, 2.4 \mathrm{mmol}$ ), $\mathrm{Pd}(\mathrm{OAc}) 2(11 \mathrm{mg}, 0.05 \mathrm{mmol})$, diisopropy-lethylamine $(0.42 \mathrm{~mL}, 2.4 \mathrm{mmol}$ ) and tri(o-tolyl)phosphine (30 mg, $0.1 \mathrm{mmol}$ ) was added to dimethylformamide $(5 \mathrm{~mL}$ ) under Ar and heated at $100{ }^{\circ} \mathrm{C}$ for $4 \mathrm{~h}$. The crude mixture was filtered from activated charcoal and water/MeOH 1: 1 was added. The forming yellow crystals were filtered (300 mg, $48 \%$ ). $1 \mathrm{H} \mathrm{NMR}$ (500 MHz, [D6] DMSO): $\delta=8.46$ (s, 1H. ArH), 8.08 (s, 2H, ArH), 7.81 (d, J = $16.1 \mathrm{~Hz}, 1 \mathrm{H},=\mathrm{CH}-$ ), $7.02(\mathrm{~d}, \mathrm{~J}=16.1 \mathrm{~Hz}, 1 \mathrm{H},=\mathrm{CH}-), 4.20(\mathrm{q}, \mathrm{J}=7.1 \mathrm{~Hz}, 1 \mathrm{H}, \mathrm{CH} 2), 1.26 \mathrm{ppm}(\mathrm{t}, \mathrm{J}=7.1 \mathrm{~Hz}, 2 \mathrm{H}, \mathrm{CH} 3) .19 \mathrm{~F}$ NMR (650 MHz, D2O): $\delta=64.5 \mathrm{ppm}$.

\section{3-(3,5-Bis(trifluoromethyl)phenyl)acrylonitrile (9):}

In a sealed tube 3,4 -bis(trifluoromethyl)bromobenzene $(0.69 \mathrm{~mL}, 4 \mathrm{mmol})$, acrylonitrile $(0.32$ $\mathrm{mL}, 4.8 \mathrm{mmol}$ ), $\mathrm{Pd}(\mathrm{OAc}) 2$ (9 $\mathrm{mg}, 0.04 \mathrm{mmol})$, diisopropyl-ethyl-amine $(0.84 \mathrm{~mL}, 4.8 \mathrm{mmol})$ and biphenyl-diisopropylphosphine $(24 \mathrm{mg}, 0.08 \mathrm{mmol}$ ) was added to dimethylacetamide $(2 \mathrm{~mL})$ under $\mathrm{Ar}$ and heated at $130{ }^{\circ} \mathrm{C}$ for $4 \mathrm{~h}$. Then $10 \mathrm{~mL}$ water and $20 \mathrm{~mL}$ methyl-tert-butylether was added to the reaction mixture and the phases were separated. The organic phase was dried over MgS04, filtered, and evaporated to silica. The residue was purified with flash column chromatography with hexane and ethyl acetate eluent mixture to give the product as a white 
solid (120 mg, 11\%). 1H NMR (500 MHz, CDCl3): $\delta=7.92$ (s, 1H, ArH), 7.88 (s, 2H, ArH), 7.47 (d, $\mathrm{J}=16.7 \mathrm{~Hz}, 1 \mathrm{H},=\mathrm{CH}-), 6.08 \mathrm{ppm}(\mathrm{d}, \mathrm{J}=16.7 \mathrm{~Hz}, 1 \mathrm{H},=\mathrm{CH}-) .13 \mathrm{C}$ NMR $(125 \mathrm{MHz}, \mathrm{CDCl} 3): \delta=$ 146.9, 135.4, 133.9 (d, J = 33.8 Hz), 127.3 (q, J = 3.9 Hz), 124.4-124.2 (m), 122.7 (d, J = 272.9 Hz), 116.6, 101.01 ppm.19F NMR (650 MHz, D20): $\delta=-62.8$ ppm. HRMS calcd. for C11H6F6N: 266.0404 ; found: 266.0396.

\section{Methyl 3-(3,5-bis(trifluoromethyl)phenyl)propiolate (10):[34]}

In a sealed tube 3,5-bis(trifluoromethyl)phenylboronic acid (218 $\mathrm{mg}, 1 \mathrm{mmol}$ ), methyl propiolate (0.13 mL, $1.5 \mathrm{mmol}$ ), copper(I) iodide (29 mg,0.15 mmol), silver(I) oxide (462 mg, $2 \mathrm{mmol}$ ) and caesium carbonate $652 \mathrm{mg}, 2 \mathrm{mmol})$ was dissolved in dichloroethane $(5 \mathrm{~mL})$. The reaction mixture was stirred under $\mathrm{Ar}$ at $80^{\circ} \mathrm{C}$ overnight. $10 \mathrm{~mL}$ water was added to the mixture then the separated organic layer was washed with brine, dried over Na2SO4, filtered, and concentrated under vacuum. The crude product was purified by flash column chromatography with mixture of hexane and ethyl acetate as eluent. The product was obtained as a light brown oil (115 mg,39\%).1H NMR (CDCl3): $\delta=8.06$ (2H, s, ArH), 7.94 (s, 1H, ArH),3.88 ppm (3H, CH3).19F NMR (650 MHz, D20): $\delta=-64.9 \mathrm{ppm}$.

\section{3,5-Bis(trifluoromethyl)phenyl vinylsulfone (11):[35]}

3,5-Bis(trifluoromethyl)thiophenol (505 $\mu \mathrm{L}, 3 \mathrm{mmol}$ ) and potassium-carbonate $(830 \mathrm{mg}, 6$ mmol) was dissolved in $\mathrm{N}, \mathrm{N}$-dimethylformamide $(25 \mathrm{~mL})$, then 2-chloroethanol $(270 \mu \mathrm{L}, 4$ mmol) was added and the mixture was stirred at RT. After 4 hours, the solventwas evaporated and the residue was dissolved in $50 \mathrm{~mL}$ ethylacetate, then washed with $50 \mathrm{~mL}$ brine. The organic layer was dried and concentrated. The crude product was dissolved in $30 \mathrm{~mL}$ dichloromethane and meta-chloroperoxybenzoic acid (1.29 g,7.5 mmol) was added slowly. The mixture was stirred for $3 \mathrm{~h}$, then it was washed with $1 \mathrm{M}$ aqueous solution of sodium hydroxide. Afte rthe extraction the organic phase was dried and concentrated, then the product was dissolved in 20 $\mathrm{mL}$ dry dichloromethane. To this solution methanesulfonyl-chloride ( $230 \mu \mathrm{l}, 3 \mathrm{mmol})$ was added at $0^{\circ} \mathrm{C}$, then triethylamine $(625 \mu \mathrm{L}, 4.5 \mathrm{mmol})$ was dropped slowly intothe mixture. After the addition of the base, the reaction was heatedup to RT and stirred for $3 \mathrm{~h}$. Finally, the solvent was removed andthe crude product was purified by column chromatography to give the 11 vinylsulfone product (128 mg, 14\%) $1 \mathrm{H} \mathrm{NMR} \mathrm{(500} \mathrm{MHz,} \mathrm{[D6]DMSO):} \delta=8.34(\mathrm{~s}, 2 \mathrm{H}), 8.13(\mathrm{~s}$, 1H), 6.74-6.61 (m, 2H), $6.24 \mathrm{ppm}(\mathrm{d}, \mathrm{J}=8.7 \mathrm{~Hz}, 1 \mathrm{H}) .19 \mathrm{~F} \mathrm{NMR} \mathrm{(650} \mathrm{MHz,} \mathrm{D2O):} \delta=-62.8 \mathrm{ppm}$.

\section{3,5-Bis(trifluoromethyl)benzyl vinylsulfone (12):}

3,5-Bis(trifluoromethyl)benzyl chloride (1313 mg, $5 \mathrm{mmol}$ ) in N,N-dimeth-ylformamide (10 mL) was added dropwise to the solution of 2-mercaptoethanol (350 $\cdot \mathrm{L}, 5 \mathrm{mmol})$ and potassium carbonate (1037 mg, $7.5 \mathrm{mmol})$ in $\mathrm{N}, \mathrm{N}$-dimethylformamide $(20 \mathrm{~mL})$, then the mixture was stirred at RT. After $3 \mathrm{~h}$, the solvent was evaporated and the residue was dissolved in $50 \mathrm{~mL}$ ethyl acetate, then washed with $50 \mathrm{~mL}$ brine. The organic layer was dried and concentrated. The crude product was dissolved in $50 \mathrm{~mL}$ dichloromethane and meta-chloroperoxybenzoic acid $(2.16 \mathrm{~g}$, $12.5 \mathrm{mmol}$ ) was added slowly. The mixture was stirred for $3 \mathrm{~h}$, and then it was washed with 1 Maqueous solution of sodium hydroxide. After the extraction theorganic phase was dried and concentrated, then the product was dissolved in $20 \mathrm{~mL}$ dry $\mathrm{CH} 2 \mathrm{Cl} 2$. To this solution methanesulfonyl-chloride ( $464 \cdot \mathrm{L}, 6 \mathrm{mmol})$ was added at $0^{\circ} \mathrm{C}$, and triethylamine $(1043 \cdot \mathrm{L}, 7.5$ mmol) was dropped slowly into the mixture. After the addition of the base, the reaction mixture 
was heated up to RT and stirred for $2 \mathrm{~h}$. Finally, the solvent was removed and the product was purified by column chromatography to obtain 12 as a white powder (328 mg, $21 \%$ ).1H NMR (500 MHz, [D6]DMSO): $\delta=8.14(\mathrm{~s}, 1 \mathrm{H}), 8.09(\mathrm{~s}, 2 \mathrm{H}), 7.00(\mathrm{dd}, \mathrm{J}=16.6,10.0 \mathrm{~Hz}, 1 \mathrm{H}), 6.26(\mathrm{~d}, \mathrm{~J}=$ $9.9 \mathrm{~Hz}, 1 \mathrm{H}), 6.08(\mathrm{~d}, \mathrm{~J}=16.6 \mathrm{~Hz}, 3 \mathrm{H}), 4.84 \mathrm{ppm}(\mathrm{s}, 6 \mathrm{H}) .13 \mathrm{C} \mathrm{NMR}(125 \mathrm{MHz}, \mathrm{CDCl} 3): \delta=136.4$, 132.8, 132.2 (2C), 131.8, 130.7 (q, J = 32.5 Hz, 2 C),123.6 (q, J = 271.3 Hz, 2 C), 122.8-122.6 (m), 57.9 ppm.19F NMR(650 MHz, D20): $\delta=-62.6$ ppm. HRMS (DUIS): [M- H]- calcd. for C11H7F602S-: 317.0076; found: 317.0046.

\section{N-(3,5-Bis(trifluoromethyl)benzyl)ethenesulfonamide (13):}

To a stirred solution of 3,5-bis(trifluoromethyl)benzyl amine (1215 $\mathrm{mg}, 5 \mathrm{mmol}$ ) and trimethylamine $(2087 \mu \mathrm{L}, 15 \mathrm{mmol})$ in $\mathrm{CH} 2 \mathrm{Cl} 2(40 \mathrm{~mL})$ at $0^{\circ} \mathrm{C}, 2$-chloroethanesulfonylchloride $(1045 \mu \mathrm{L}, 10 \mathrm{mmol})$ was added drop-wise. The resulting mixture was then stirred at $0^{\circ} \mathrm{C}$ until the aminewas consumed as determined by TLC. The reaction was quenched with water (300 $\mathrm{mL})$ and the mixture was extracted with $\mathrm{CH} 2 \mathrm{Cl} 2(3 \times 25 \mathrm{~mL})$. The combined organic extracts were washed with brine $(10 \mathrm{~mL})$, dried with anhydrous $\mathrm{Na} 2 \mathrm{SO} 4$. The solvent was removed under vacuum and the residue was purified by column chromatography with a mixture of hexane and ethyl acetate as the eluent, to give the product as a white powder (882 mg, 53\%).1H NMR(500 MHz, [D6]DMSO): $\delta=8.04(\mathrm{t}, \mathrm{J}=6.3 \mathrm{~Hz}, 1 \mathrm{H}$ ), $8.03(\mathrm{~s}, 2 \mathrm{H}), 8.00(\mathrm{~s}, 1 \mathrm{H}) 6.74(\mathrm{dd}, \mathrm{J}=16.5,10.0 \mathrm{~Hz}$, $1 \mathrm{H}), 6.06(\mathrm{~d}, \mathrm{~J}=16.5 \mathrm{~Hz}, 1 \mathrm{H}), 5.98(\mathrm{~d}, \mathrm{~J}=10.0 \mathrm{~Hz}, 1 \mathrm{H}), 4.28 \mathrm{ppm}(\mathrm{d}, \mathrm{J}=6.3 \mathrm{~Hz}, 2 \mathrm{H}) .13 \mathrm{C}$ NMR (125 MHz, [D6]DMSO): $\delta=147.3,142.0,135.4$ (q, J= $32.5 \mathrm{~Hz}, 2 \mathrm{C}$ ), 133.6 (2C), 131.2,128.5 (q, J = 271.3 Hz, 2 C), 126.3-126.0 (m), 49.9 ppm.19F NMR(650 MHz, D20): $\delta=-62.6$ ppm. HRMS (DUIS): [MH]-calcd. forC11H8F6NO2S-: 332.0185; found: 332.0157.

\section{1-(Isothiocyanatomethyl)-3,5-bis(trifluoromethyl)benzene (15):}

In a round bottom flask 1,1'-thiocarbonylbis(pyridin-2(1H)-one) (3 mmol, $0.7 \mathrm{~g}$ ) was dissolved in $\mathrm{CH} 2 \mathrm{Cl} 2(100 \mathrm{~mL}) .3,5$-Bistrifluoromethylbenzylamine $(0.24 \mathrm{~g}, 1 \mathrm{mmol})$ was dissolved in dichloromethane $(50 \mathrm{~mL})$ and added dropwise. The reaction mixture was stirred at RT for 50 min. Then the reaction mixture was washed with brine $(2 \times 20 \mathrm{~mL})$ and $1 \mathrm{M} \mathrm{HCl}(20 \mathrm{~mL})$, and the organic phase was dried over MgSO4. The solvent was evaporated, and the crude product was purified with flash column chromatography using hexane and ethyl acetate as the eluent (9: 1 ) resulting in the product as a colourless oil (171 mg, $60 \%)$. $1 \mathrm{H} \mathrm{NMR} \mathrm{(500} \mathrm{MHz,} \mathrm{CDCl3):} \delta=7.88$ (s, 1H, ArH), 7.79 (s, 2H, ArH), 4.89 ppm (s, 2H, CH2). 13C NMR (125 MHz, CDCl3) 185.4 (d, J = $338.6 \mathrm{~Hz}$ ), 140.0, 132.2 (d, J = 33.5 Hz), 127.7-127.5 (m), 124.1, 122.0-121.7 (m), 47.6 ppm.19F NMR (650 MHz, D20): $\delta=-64.4$ ppm. HRMS (DUIS): [M- H]-calcd. for C10H4F6NS-: 283.9968;found: 283.9967.

\section{tert-Butyl 2-(3,5-bis(trifluoromethyl)benzylidene)hydrazine carboxylate (19):}

3,5-Bis(trifluoromethyl)benzaldehyde $(0,16 \mathrm{~mL}, 1 \mathrm{mmol})$ and tert-butyl hydrazinecarboxylate (145 mg, $1.1 \mathrm{mmol}$ ) were dissolved in $1: 1$ mixture of tetrahydrofuran and dichloromethane (30 $\mathrm{mL}$ ). Then catalytic amount of $\mathrm{H} 2 \mathrm{SO} 4$ (1-2 drops) was added and the reaction was stirred at RT for $2 \mathrm{~h}$. The solvent was removed under vacuum, then crude product was filtered through a silica pad using dichloromethane-methanol solvent mixture. Then $25 \mathrm{~mL}$ water and $25 \mathrm{~mL}$ ethyl acetate was added to the residue. After the separation, the organic layer was washed with brine, dried over Na2SO4, filtered, and concentrated under vacuum. The product was obtained by flash column chromatography with a mixture of hexane and ethyl acetate as the eluent. The product 
was obtained as a yellow powder (281 mg, 78\%). 1H NMR (500 MHz, [D6]DMSO): $\delta=11.29$ (s, $1 \mathrm{H}, \mathrm{NH}), \quad 8.25 \quad(\mathrm{~s}, \quad 2 \mathrm{H}, \mathrm{ArH}), 8.15(\mathrm{~s}, 1 \mathrm{H}, \mathrm{ArH}), 8.05(\mathrm{~s}, 1 \mathrm{H},=\mathrm{CH}-), 1.46 \mathrm{ppm} \quad(\mathrm{s}$, 9H,CH3) . 13C NMR (125 MHz, [D6]DMSO): $\delta=152.7,138.0$ (2C), 131.2 (q, J = 33.1 Hz, $2 \mathrm{C}$ ), 126.9-127.1 (m, 3 C), 124.7, 122.6, 80.4, 29.4 ppm (3 C). 19F NMR (650 MHz, D20): $\delta=62.7$ ppm. HRMS (ESI): [M+H]+ calcd. for C14H14F6N2O2 + : 357.1037; found: 357.1039.

\section{N-(3,5-Bis(trifluoromethyl)benzyl)cyanamide (20):}

To a cooled solution $\left(0^{\circ} \mathrm{C}\right.$ ) of 3,5-bis(trifluoromethyl)benzyl amine (486 $\mathrm{mg}, 2 \mathrm{mmol}$ ) in dry diethyl ether $(20 \mathrm{~mL})$ cyanogen bromide as $3 \mathrm{M}$ solution in $\mathrm{CH} 2 \mathrm{Cl} 2(100 \mu \mathrm{L}, 2 \mathrm{mmol})$ was added dropwise. The reaction was warmed to RT and stirred for $16 \mathrm{~h}$. The mixture was filtered to remove the residual salt and the filtrate was concentrated. The residue was diluted in $25 \mathrm{~mL}$ ethyl acetate, washed with water $(30 \mathrm{~mL})$ and brine $(30 \mathrm{~mL})$. Organic extracts was dried over $\mathrm{Na} 2 \mathrm{SO}$, filtered, and concentrated under vacuum. The product was obtained by flash column chromatography with a mixture of hexane and ethyl acetate as the eluent. Compound 20 was obtained as a white solid (453 mg, 34\%). $1 \mathrm{H} \mathrm{NMR} \mathrm{(500} \mathrm{MHz,} \mathrm{[D6]} \mathrm{DMSO):} \delta=8.05$ (s, 1H), 7.41 (s, 1H), $4.34 \mathrm{ppm}(\mathrm{d}, \mathrm{J}=4.0 \mathrm{~Hz}, 1 \mathrm{H}) .13 \mathrm{CNMR}(125 \mathrm{MHz}, \mathrm{CDCl} 3): \delta=142.0,130.9$ (q, J = $32.8 \mathrm{~Hz}, 2$ C), $129.0(2 \mathrm{C}$ ), 123.7 (q, J = 268.3 Hz, 2 C), 122.7-121.9 (m), 117.2, 47.6 ppm.19F NMR (650 MHz, D20): $\delta=-62.5$ ppm. HRMS (DUIS): [M- H]-calcd. for C10H5F6N2-: 267.0362; found: 267.0325.

\section{N-(3,5-Bis(trifluoromethyl)phenyl)-2-chloroacetamide (21):[36]}

The same procedure as for 1 except using chloroacetyl chloride $(0.80 \mathrm{~mL}, 10 \mathrm{mmol})$. Pure 21 was obtained as a white powder(2.31 g, $75 \%) .1 \mathrm{H} \mathrm{NMR} \mathrm{(500} \mathrm{MHz,} \mathrm{[D6]DMSO):} \delta=10.90$ (s, 1H, $\mathrm{NH}), 8.24$ (s, 2H, ArH), 7.80 (s, 1H, ArH), $4.32 \mathrm{ppm}(\mathrm{s}, 2 \mathrm{H}, \mathrm{CH} 2 \mathrm{Cl}) .19 \mathrm{~F}$ NMR(650 MHz, D2O): $\delta=-$ $62.7 \mathrm{ppm}$.

\section{N-(3,5-Bis(trifluoromethyl)phenyl)-2-chloropropanamide (22):[31]}

The same procedure as for 1 except using 2-chloropropanoyl chloride(0.97 mL, $10 \mathrm{mmol}$ ) and the reaction mixture was allowed to stir at RT overnight. Crude product was purified by flash column chromatography with a mixture of hexane and ethyl acetate as an eluent to give the pure product as a white powder (1.35 g, 42\%).1HNMR (500 MHz, CDCl3): $\delta=10.21(\mathrm{~s}, 1 \mathrm{H}, \mathrm{NH}), 8.34$ (s, 2H, ArH), 7.68(s, 1H, ArH), $5.38(\mathrm{q}, \mathrm{J}=7.0 \mathrm{~Hz}, 1 \mathrm{H}, \mathrm{CHCl}), 1.99 \mathrm{ppm}(\mathrm{d}, \mathrm{J}=7.1 \mathrm{~Hz}, 3 \mathrm{H}, \mathrm{CH} 3) .19 \mathrm{~F}$ NMR (650 MHz, D20): $\delta=-62.7 \mathrm{ppm}$.

\section{N-(3,5-Bis(trifluoromethyl)phenyl)-2-bromopropanamide (23):[31]}

The same procedure as for 1 except using 2-bromopropanoyl chloride $(1.01 \mathrm{~mL}, 10 \mathrm{mmol})$, and the reaction mixture was allowed to stir atRT for 2 days. Crude product was purified by flash column chromatography with a mixture of hexane and ethyl acetate as aneluent to give the pure product as a brown powder (1.38 g, $38 \%$ ). $1 \mathrm{H} \mathrm{NMR} \mathrm{(500} \mathrm{MHz,} \mathrm{[D6]DMSO):} \delta=10.95$ (s, $1 \mathrm{H}, \mathrm{NH}$ ), 8.25 (s, 1H,ArH), $7.78(\mathrm{~s}, 1 \mathrm{H}, \mathrm{ArH}), 4.67(\mathrm{q}, \mathrm{J}=6.7 \mathrm{~Hz}, 1 \mathrm{H}, \mathrm{CHBr}), 1.76 \mathrm{ppm}(\mathrm{d}, \mathrm{J}=6.7 \mathrm{~Hz}, 1 \mathrm{H}$, CH3).19F NMR (650 MHz, D20): $\delta=-62.7 \mathrm{ppm}$.

\section{1-(3,5-Bis(trifluoromethyl)phenyl)-2-bromoethanone (24):[37]}

To astirred solution of 3',5'-bis(trifluoromethyl)acetophenone $(0.18 \mathrm{~mL}, 1 \mathrm{mmol})$ in THF (10 mL) pyridinium tribromide $(0.32 \mathrm{~mL}, 1 \mathrm{mmol})$ dissolved in THF $(10 \mathrm{~mL})$ was added dropwise. The reaction mixture was stirred for $4 \mathrm{~h}$. Water $(20 \mathrm{~mL})$ was added, and the phases were separated. 
The aqueous phase was extracted with ethyl acetate $(2 \times 20 \mathrm{~mL})$. The organic phase was dried over MgSO4and evaporated. Flash column chromatography using hexane/ethyl acetate (95:5) asthe eluent afforded the product as a yellow oil that solidified overnight (190 mg, $57 \%$ ).1H NMR (500 MHz, [D6]DMSO): $\delta=8.55$ (s,2H, ArH), 8.44 (s, 1H, ArH), $5.12 \mathrm{ppm}(\mathrm{s}, 2 \mathrm{H}, \mathrm{CH} 2 \mathrm{Br}) .19 \mathrm{~F}$ $\operatorname{NMR}(650 \mathrm{MHz}, \mathrm{D} 20): \delta=-62.7 \mathrm{ppm}$.

\section{2-(3,5-Bis(trifluoromethyl)phenyl)oxirane (25):[38]}

3,5-Bistrifluorometh-ylphenyl-styrene $(0.36 \mathrm{~mL}, 2 \mathrm{mmol})$ was dissolved in chloroform $(20 \mathrm{~mL})$, and meta-chloroperoxybenzoic acid $(1.38 \mathrm{~g}, 4 \mathrm{mmol})$ was added at $0^{\circ} \mathrm{C}$. The reaction mixture was stirred overnight, followed by washing with saturated NaHCO3 $(10 \mathrm{~mL})$. The organic phase was dried over MgSO4and evaporated. The crude product was purified with flash chromatography using hexane/ethyl acetate (93:7) as the eluent, resulting in the product as a colourless oil (364 mg,71\%).1H NMR (500 MHz, CDCl3): $\delta=7.82(\mathrm{~s}, 1 \mathrm{H}, \mathrm{ArH}), 7.74(\mathrm{~s}, 2 \mathrm{H}, \mathrm{ArH})$, 3.99 (dd, J = 3.8, 2.6 Hz, 1H, CH2O), 3.23 (dd, J = 5.3, $4.1 \mathrm{~Hz}, 1 \mathrm{H}, \mathrm{CH} 2 \mathrm{O}), 2.79 \mathrm{ppm}(\mathrm{dd}, \mathrm{J}=5.4,2.4$ $\mathrm{Hz}, 1 \mathrm{H}, \mathrm{CH} 20) .19 \mathrm{~F}$ NMR (650 MHz,D20): $\delta=-62.6 \mathrm{ppm}$.

Acknowledgements

The research was funded by H2020 MSCA Fragnet (project675899), SNN 125496, OTKA PD124598 and 2018-2.1.11-TÉT SI-2018-00005, NVKP_16-1-2016-0020 and NKP-2018-1.2.1-NKP-201800005 (National Research, Development and Innovation Office of Hungary), the ELTE Thematic Excellence Programme and BME-Biotechnology FIKP grant (BME FIKP-BIO) supported by the Hungarian Ministry for Innovation and Technology, the Slovenian Research Agency (grants Z11859, N1-0068, J3-1745, J1-8145 and P1-0208), and a grant from the Hessian Landes-Offensive zur Entwicklung Wissenschaftlich-ökonomischer Exzellenz (LOEWE TRABITA). K.N. was supported by the ÚNKP-20-4 (ÚNKP-20-4-II-BME-311) New National Excellence Program of the Ministry for Innovation and Technology from the source of the National Research, Development and Innovation Fund. The work of A. Scarpino, K. Németh, G. Koppány and I. Vida is gratefully acknowledged.

Conflict of Interest

The authors declare no conflict of interest.

Keywords: drug design $\cdot$ electrophilic warheads $\cdot \mathrm{KRASG12C} \cdot \mathrm{MAO} \cdot$ targeted covalent inhibitors 
[1] a) T. A. Baillie, Angew. Chem. Int. Ed. 2016, 55, 13408-13421; Angew. Chem. 2016, 128, 13606-13619; b) R. A. Bauer, Drug Discovery Today 2015, 20, 1061-1073; c) A. Vasudevan, M. A. Argiriadi, A. Baranczak, M. Friedman, J. Gavrilyuk, A. D. Hobson, J. J. Hulce, S. Osman, N. S. Wilson, Prog. Med. Chem. 2019, 58, 1-62.

[2] D. A. Shannon, E. Weerapana, Curr. Opin. Chem. Biol. 2015, 24, 18-26.

[3] a) A. J. T. Smith, X. Zhang, A. G. Leach, K. N. Houk, J. Med. Chem. 2009, 52, 225-233; b) C. González-Bello, ChemMedChem 2016, 11, 22-30.

[4] A. Tuley, W. Fast, Biochemistry 2018, 57, 3326-3337.

[5] M. Gersch, J. Kreuzer, S. A. Sieber, Nat. Prod. Rep. 2012, 29, 659-682.

[6] a) T. Zhang, J. M. Hatcher, M. Teng, N. S. Gray, M. Kostic, Cell Chem. Biol. 2019, 26. 1486-1500; b) M. Gehringer, S. A. Laufer, J. Med. Chem. 2019 , 62, 5673-5724; c) J. S. Martin-Claire, J. McKenzie, D. F. lan, H. Gilbert, Bioorg. Med. Chem. 2019, 27, 2066-2074.

[7] S. G. Kathman, A. V. Statsyuk, MedChemComm 2016, 7, 576-585.

[8] a) A. M. Embaby, S. Schoffelen, C. Kofoed, M. Meldal, F. Diness, Angew. Chem. Int. Ed. 2018, 57, 8022-8026; Angew. Chem. 2018, 130, 81548158; b) P. Martin-Gago, C. A. Olsen, Angew. Chem. Int. Ed. 2019, 58, 957-966.

[9] E. Weerapana, C. Wang, G. M. Simon, F. Richter, S. Khare, M. B. D. Dillon, D. A. Bachovchin, K. Mowen, D. Baker, B. F. Cravatt, Nature 2010, 468, 790-795.

[10] a) W. Zhang, J. Pei, L. Lai, J. Chem. Inf. Model. 2017, 57, 1453-1460; b) E. Awoonor-Williams, C. N. Rowley, J. Chem. Inf. Model. 2018, 58, 19351946; c) R. Liu, Z. Yue, C. C. Tsai, J. Shen, J. Am. Chem. Soc. 2019, 141, 6553-6560; d) Z. Zhao, Q. Liu, S. Bliven, L. Xie, P. E. Bourne, J. Med. Chem. 2017, 60, 2879-2889.

[11] a) E. Resnick, A. Bradley, J. Gan, A. Douangamath, T. Krojer, R. Sethi, P. P. Geurink, A. Aimon, G. Amitai, D. Bellini, J. Bennett, M. Fairhead, O. Fedorov, R. Gabizon, J. Gan, J. Guo, A. Plotnikov, N. Reznik, G. F. Ruda, L. Diaz-Sáez, V. M. Straub, T. Szommer, S. Velupillai, D. Zaidman, Y. Zhang, A. R. Coker, C. G. Dowson, H. M. Barr, C. Wang, K. V. M. Huber, P.E. Brennan, H. Ovaa, F. von Delft N London, J. Am. Chem. Soc. 2019, 141, 8951-8968; b) A. Keeley, L. Petri, P. Ábrányi-Balogh, G. M. Keserũ, Drug Discovery Today 2020. 25, 983-996.

[12] a) P. Ábrányi-Balogh, L. Petri, T. Imre, P. Szijj, A. Scarpino, M. Hrast, A. Mitrović, U. P. Fonovič, K. Németh, H. Barreteau, D. I. Roper, K. Horváti, G. G. Ferenczy, J. Kos, J. llaš, S. Gobec, G. M. Keserü, Eur. J. Med. Chem. 2018, 160, 94-107; b) E. H. Krenske, R. C. Petter, K. N. Houk, J. Org. Chem. 2016, 81, 11726-11733; c) V.J. Cee, L.P. Volak, Y. Chen, M. D. Bartberger, C. Tegley, T. Arvedson, J. McCarter, A. S. Tasker, C. Fotsch, J. Med. Chem. 2015, 58, 9171-9178; d) R. Lonsdale, J. Burgess, N. Colclough, N. L. Davies, E. M. Lenz, A. L. Orton, R. A. Ward, J. Chem. Inf. Model. 2017, 57, 3124-3137; e) A. A. Adhikari, T. C. M. Seegar, S. B. Ficarro, M. D. McCurry, D. Ramachandran, L. Yao, S. N. Chaudhari, S. Ndousse-Fetter, A. S. Banks, J. A. Marto, S. C. Blacklow, A. S. Devlin, Nat. Chem. Biol. 2020, 16, 318-326. 
[13] a) A. Liu, X. Wang, X. Ou, M. Huang, C. Chen, S. Liu, L. Huang, X. Liu, C. Zhang, Y. Zheng, Y. Ren, L. He, J. Yao, J. Agric. Food Chem. 2008, 56, 6562-6566; b) B. Lallemand, F. Chaix, M. Bury, C. Bruyère, J. Ghostin, J.P. Becker, C. Delporte, M. Gelbcke, V. Mathieu, J. Dubois, M. Prévost, L. Jabin, R. Kiss, J. Med. Chem. 2011, 54, 6501-6513.

[14] M. E. Flanagan, J. A. Abramite, D. P. Anderson, A. Aulabaugh, U. P. Dahal, A. M. Gilbert, C. Li, J. Montgomery, S. R. Oppenheimer, T. Ryder, B. P. Schuff, D. P. Uccello, G. S. Walker, Y. Wu, M. F. Brown, J. M. Chen, M. M. Hayward, M. C. Noe, R. S. Obach, L. Philippe, V. Shanmugasundaram, M. J. Shapiro, J. Starr, J. Stroh, Y. Che, J. Med. Chem. 2014, 57, 1007210079 .

[15] L. M. Serafimova, M. A. Pufall, S. Krishnan, K. Duda, M. S. Cohen, R. L. Maglathlin, J.M. McFarland, R. M. Miller, M. Frödin, J. Taunton, Nat. Chem. Biol. 2012, 8, 471-476.

[16] H. Han, Y. Yang, S. H. Olesen, A. Becker, S. Betzi, E. Schönbrunn, Biochemistry 2010, 49, 4276-4282.

[17] L. De Colibus, M. Li, C. Binda, A. Lustig, D. E. Edmondson, A. Mattevi, Proc. Natl. Acad. Sci. USA 2005, 102, 12684-12689.

[18] A. Chakrabarti, I. Oehme, O. Witt, G. Oliveira, W. Sippl, C. Romier, R. J. Pierce, M. Jung, Trends Pharmacol. Sci. 2015, 36, 481-492.

[19] O. Witt, H. E. Deubzer, T. Milde, I. Oehme, Cancer Lett. 2009, 277, 8-21.

[20] M. Muth, N. Jänsch, A. Kopranovic, A. Krämer, N. Wōssner, M. Jung, F. Kirschhōfer, G. Brenner-Weiß, F.-J. Meyer-Almes, Biochim. Biophys. Acta Gen. Subj. 2019, 1863, 577-585.

[21] T. A. Thibaudeau, D. M. Smith, Pharmacol. Rev. 2019, 71, 170-197.

[22] J. M. L. Ostrem, K. M. Shokat, Nat. Rev. Drug Discovery 2016, 15, 771-785.

[23] R. J. Simpson, CSH. Protoc. 2008, pdb.prot4699.

[24] K. Rožman, S. Lešnik, B. Brus, M. Hrast, M. Sova, D. Patin, H. Barreteau, J. Konc, D. Janežič, S. Gobec, Bioorg. Med. Chem. Lett. 2017, 27, 944-949.

[25] O.-M. Bautista-Aguilera, A. Samadi, M. Chioua, K. Nikolic, S. Filipic, D. Agbaba, E. Soriano, L. de Andrés, M. I. Rodriguez-Franco, S. Alcaro, R. R. Ramsay, F. Ortuso, M. Yañez, J. Marco-Contelles, J. Med. Chem. 2014, 57 , 10455-10463.

[26] H. von der Eltz, H.-J. Guder, K. Muehlegger, US4900822 1990.

[27] M. Li, F. Hubálek, P. Newton-Vinson, D. E. Edmondson, Protein Expression Purif. 2002, 24, 152-162.

[28] F. Hubálek, J. Pohl, D. E. Edmondson, J. Biol. Chem. 2003, 278, 2861228618.

[29] http://prospector.ucsf.edu/prospector/mshome.htm (retrieved on 10.8.2020).

[30] G. Pálfy, I. Vida, A. Perczel, Biomol. NMR Assign. 2020, 14, 1-7.

[31] B. F. Cravatt, WO2017210600/A1, 2017.

[32] R. Callahan, O. Ramirez, K. Rosmarion, R. Rothchild, K. C. Bynum, J. Heterocycl. Chem. 2005, 42, 889-898.

[33] Y.-H. Zhang, B.-F. Shi, J.-Q. Yu, J. Am. Chem. Soc. 2009, 131, 5072-5074.

[34] A. W.-H. Cheung, S. B. Ferguson, L. H. Foley, A. J. Lovey, US6310247/B1, 2001.

[35] L. Al-Riyami, M. A. Pineda, J. Rzepecka, J. K. Huggan, A. I. Khalaf, C. J. Suckling, F. J. Scott, D. T. Rodgers, M. M. Harnett, W. Harnett, J. Med. Chem. 2013, 56, 9982-10002.

[36] T. R. K. Reddy, C. Li, X. Guo, P. M. Fischer, L. V. Dekker, Bioorg. Med. Chem. 2014, 22, 5378-5391.

[37] Z.-W. Chen, D.-N. Ye, M. Ye, Z.-G. Zhou, S.-H. Li, L.-X. Liu, Tetrahedron Lett. 2014, 55, 1373-1375.

[38] S. A. Weissman, K. Rossen, P. J. Reider, Org. Lett. 2001, 3, 2513-2515. 